\title{
Chemopreventive Strategies for Inflammation-Related Carcinogenesis: Current Status and Future Direction
}

\author{
Yusuke Kanda ${ }^{1}$, Mitsuhiko Osaki ${ }^{1,2}$ and Futoshi Okada ${ }^{1,2, *}$ \\ 1 Division of Pathological Biochemistry, Tottori University Faculty of Medicine, Yonago, Tottori 683-8503, \\ Japan; kanda@med.tottori-u.ac.jp (Y.K.); osamitsu@med.tottori-u.ac.jp (M.O.) \\ 2 Chromosome Engineering Research Center, Tottori University, Yonago, Tottori 683-8503, Japan \\ * Correspondence: fuokada@med.tottori-u.ac.jp; Tel.: +81-859-38-6241; Fax: +81-859-38-6240
}

Academic Editors: Takuji Tanaka and Masahito Shimizu

Received: 31 March 2017; Accepted: 17 April 2017; Published: 19 April 2017

\begin{abstract}
A sustained and chronically-inflamed environment is characterized by the presence of heterogeneous inflammatory cellular components, including neutrophils, macrophages, lymphocytes and fibroblasts. These infiltrated cells produce growth stimulating mediators (inflammatory cytokines and growth factors), chemotactic factors (chemokines) and genotoxic substances (reactive oxygen species and nitrogen oxide) and induce DNA damage and methylation. Therefore, chronic inflammation serves as an intrinsic niche for carcinogenesis and tumor progression. In this article, we summarize the up-to-date findings regarding definitive/possible causes and mechanisms of inflammation-related carcinogenesis derived from experimental and clinical studies. We also propose 10 strategies, as well as candidate agents for the prevention of inflammation-related carcinogenesis.
\end{abstract}

Keywords: inflammation-related carcinogenesis; chronic inflammation; chemoprevention

\section{Introduction}

In 1863, Rudolf Virchow hypothesized that cancers occurred at sites of chronic inflammation [1]. This hypothesis has been confirmed by epidemiological and experimental pathological studies. Parkin showed that infection-related inflammation contributed to approximately $20 \%$ of all cancer cases worldwide [2]. Inflammation-inducible factors, such as air pollution, foreign bodies and ultraviolet radiation, are also associated with carcinogenesis [3].

Since chronic inflammation is associated with more than one-fifth of cancer incidence, there is an urgent need to explore chemopreventive agents against inflammation-related carcinogenesis. Before clinical trials of such agents are initiated, it is necessary to understand the pathogenesis of inflammation-related carcinogenesis by using animal models [4]. For example, rodent models for Helicobacter pylori and inflammatory bowel disease, which are the major causes of human gastric and colon cancers, respectively, have been developed to elucidate the underlying pathogenic mechanisms [4,5]. Epidemiological studies have shown that chronic inflammation predisposes individuals to various cancers, including cancer of the gastrointestinal tract [6]. Therefore, the use of agents targeted against inflammatory mediators might be a promising approach to prevent various types of inflammation-related cancers. To date, food products, natural compounds and synthetic low-molecular-weight compounds have been shown to suppress inflammation-related carcinogenesis. In this review, we summarize the mechanisms of inflammation-induced carcinogenesis by classifying the mechanisms of action of chemopreventive agents, and we propose 10 strategies for the prevention of carcinogenesis. 


\section{Causes of Inflammation-Related Carcinogenesis}

The International Agency for Research on Cancer (IARC), through its IARC Monographs Programme, has performed carcinogenic hazard assessment of agents in humans based on experimental and clinical reports [7]. In this assessment, agents are classified into five groups (Group 1, 2A, 2B, 3 and 4). Group 1 carcinogens are those that are definitely carcinogenic to humans (Table 1 ). Table 1 also summarizes presumed carcinogenic agents classified into Group 2A to 3, as well as other previously-reported presumed carcinogenic agents not included in the IARC study.

Table 1. Cause-and-effect relationship between inflammation and its associated carcinogenesis in humans.

\begin{tabular}{|c|c|c|c|}
\hline \multirow{2}{*}{$\begin{array}{l}\text { Sites of Inflammation-Related } \\
\text { Carcinogenesis }\end{array}$} & \multicolumn{3}{|c|}{ Causes of Inflammation/Pathological Condition } \\
\hline & $\begin{array}{l}\text { Definitely Carcinogenic Agents } \\
\text { (Group 1) }\end{array}$ & 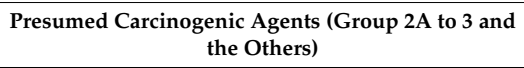 & References \\
\hline \multirow{2}{*}{ Eye } & HIV type 1 & & [8] \\
\hline & & UV-associated skin inflammation & [8] \\
\hline Lip & & UV-associated skin inflammation & [8] \\
\hline \multirow{6}{*}{ Oral cavity } & HPV type 16 & & [8] \\
\hline & & HPV type 18 & [8] \\
\hline & & Gingivitis & [9] \\
\hline & & Lichen planus & [9] \\
\hline & & Leukoplakia & [10] \\
\hline & & Periodontitis & [11] \\
\hline Salivary gland & & Sialadenitis & [9] \\
\hline \multirow{2}{*}{ Tongue } & & HPV & [12] \\
\hline & & Caries & [13] \\
\hline Tonsil & HPV type 16 & & {$[8,12]$} \\
\hline Nasopharynx & EBV & & {$[8,10,12]$} \\
\hline \multirow{2}{*}{ Pharynx } & HPV type 16 & & [8] \\
\hline & & Asbestos & [8] \\
\hline Oropharynx & & HPV & [12] \\
\hline \multirow{2}{*}{ Larynx } & Asbestos & & {$[8]$} \\
\hline & & HPV type 16 & [8] \\
\hline Thyroid & & $\begin{array}{l}\text { Chronic lymphocytic thyroiditis } \\
\text { Hashimoto's thyroiditis }\end{array}$ & $\begin{array}{l}{[14]} \\
{[14]}\end{array}$ \\
\hline \multirow{6}{*}{ Esophagus } & & Gastric reflux, esophagitis & {$[9,10]$} \\
\hline & & Barrett's esophagus & [10] \\
\hline & & Barrett's metaplasia & [9] \\
\hline & & Neisseria mucosa & [15] \\
\hline & & Neisseria sicca & [15] \\
\hline & & Neisseria subflava & [15] \\
\hline \multirow{14}{*}{ Lung } & Asbestos & & [8] \\
\hline & Coal gasification & & [8] \\
\hline & Outdoor air pollution & & {$[8,10,16]$} \\
\hline & Tobacco smoke/smoking & & {$[8,10]$} \\
\hline & & Asthma & [17] \\
\hline & & Bronchitis & [9] \\
\hline & & COPD & [18] \\
\hline & & Interstitial pneumonia & [19] \\
\hline & & Sarcoidosis & [20] \\
\hline & & Silicosis & [9] \\
\hline & & Tuberculosis & [21] \\
\hline & & Chlamydia pneumoniae & [22] \\
\hline & & HPV type 16 & [23] \\
\hline & & HIV type 1 & [24] \\
\hline \multirow{2}{*}{ Lung mesothelium } & Asbestos & & {$[8,10]$} \\
\hline & & Silicosis & [25] \\
\hline \multirow{2}{*}{ Breast } & & HERV-K & [26] \\
\hline & & Inflammatory breast cancer & [10] \\
\hline
\end{tabular}


Table 1. Cont.

\begin{tabular}{|c|c|c|c|}
\hline \multirow[b]{2}{*}{$\begin{array}{l}\text { Sites of Inflammation-Related } \\
\text { Carcinogenesis }\end{array}$} & \multicolumn{3}{|c|}{ Causes of Inflammation/Pathological Condition } \\
\hline & $\begin{array}{l}\text { Definitely Carcinogenic Agents } \\
\text { (Group 1) }\end{array}$ & $\begin{array}{l}\text { Presumed Carcinogenic Agents (Group 2A to } 3 \text { and } \\
\text { the Others) }\end{array}$ & References \\
\hline \multirow{4}{*}{ Stomach } & Helicobacter pylori & & {$[8,10,12]$} \\
\hline & & Asbestos & [8] \\
\hline & & EBV & {$[8,10]$} \\
\hline & & Chronic atrophic gastritis & [10] \\
\hline \multirow{11}{*}{ Liver } & HBV & & {$[8,10,12]$} \\
\hline & $\mathrm{HCV}$ & & {$[8,10,12]$} \\
\hline & Clonorchis sinensis & & {$[8,10]$} \\
\hline & Opisthorchis viverrini & & {$[8,10]$} \\
\hline & & Cirrhosis & [10] \\
\hline & & HDV & [27] \\
\hline & & HIV type 1 & [8] \\
\hline & & Schistosoma japonicum & {$[8,10]$} \\
\hline & & Hemochromatosis & [28] \\
\hline & & $\alpha$-1-anti-trypsin deficiency & [28] \\
\hline & & Alcohol & [28] \\
\hline \multirow{4}{*}{ Bile duct } & Clonorchis sinensis & & [12] \\
\hline & Opisthorchis viverrini & & [12] \\
\hline & & Primary sclerosing cholangitis & [29] \\
\hline & & Bile acids-associated cholangitis & [9] \\
\hline \multirow{5}{*}{ Gall bladder } & & Gall bladder stone-associated cholecystitis & {$[9,10]$} \\
\hline & & Primary sclerosing cholangitis & [29] \\
\hline & & Pancreaticobiliary maljunction & [30] \\
\hline & & Salmonella typhimurium & [10] \\
\hline & & Salmonella enterica serovar Typhi & [31] \\
\hline \multirow{4}{*}{ Pancreas } & & Chronic pancreatitis & [10] \\
\hline & & Alcoholism-associated pancreatitis & [9] \\
\hline & & Hereditary pancreatitis & [32] \\
\hline & & Alcohol & [33] \\
\hline \multirow{14}{*}{ Colon and Rectum } & & Bile acids-associated coloproctitis & [9] \\
\hline & & Inflammatory bowel diseases & {$[9,10,34]$} \\
\hline & & Cytomegalovirus & [35] \\
\hline & & EBV & [35] \\
\hline & & HPV & [35] \\
\hline & & JCV & [35] \\
\hline & & Bacteroides & [35] \\
\hline & & Clostridium septicum & [36] \\
\hline & & Escherichia coli & [35] \\
\hline & & Helicobacter pylori & [35] \\
\hline & & Streptococcus bovis & [35] \\
\hline & & Streptococcus gallolyticus & [37] \\
\hline & & Schistosoma japonicum & {$[8,10]$} \\
\hline & & Asbestos & [8] \\
\hline \multirow{3}{*}{ Bladder } & Schistosoma haematobium & & {$[8,10,12,38]$} \\
\hline & & Cystitis & [10] \\
\hline & & Urinary catheter-associated cystitis & {$[9,39]$} \\
\hline \multirow{4}{*}{ Anus } & HIV type 1 & & [8] \\
\hline & HPV type 16 & & [8] \\
\hline & & HPV types 18,33 & [8] \\
\hline & & Anal fistula & [40] \\
\hline Testis & & EBV & [41] \\
\hline \multirow{4}{*}{ Prostate } & & Prostatitis & [42] \\
\hline & & Proliferative inflammatory atrophy & [10] \\
\hline & & Gonorrhea & [43] \\
\hline & & Trichomonas vaginalis & [44] \\
\hline \multirow{3}{*}{ Ovary } & Asbestos & & [8] \\
\hline & & Pelvic inflammatory disease & [9] \\
\hline & & Endometriosis & [45] \\
\hline
\end{tabular}


Table 1. Cont.

\begin{tabular}{|c|c|c|c|}
\hline \multirow[b]{2}{*}{$\begin{array}{l}\text { Sites of Inflammation-Related } \\
\text { Carcinogenesis }\end{array}$} & \multicolumn{3}{|c|}{ Causes of Inflammation/Pathological Condition } \\
\hline & $\begin{array}{l}\text { Definitely Carcinogenic Agents } \\
\text { (Group 1) }\end{array}$ & $\begin{array}{l}\text { Presumed Carcinogenic Agents (Group 2A to } 3 \text { and } \\
\text { the Others) }\end{array}$ & References \\
\hline \multirow{4}{*}{ Uterine cervix } & $\begin{array}{c}\text { HPV types } 16,18,31,33,35,39,45,51 \\
52,56,58,59\end{array}$ & & [8] \\
\hline & HIV type 1 & & [8] \\
\hline & & HPV types $26,53,66,67,68,70,73,82$ & [8] \\
\hline & & Herpes simplex virus & [10] \\
\hline \multirow{3}{*}{ Penis } & HPV type 16 & & [8] \\
\hline & & HIV types 1 & [8] \\
\hline & & HPV types 18 & [8] \\
\hline \multirow{4}{*}{ Vulva } & HPV type 16 & & [8] \\
\hline & & HIV types 1 & [8] \\
\hline & & HPV types 18,33 & [8] \\
\hline & & Lichen sclerosis & {$[9,46]$} \\
\hline \multirow{2}{*}{ Vagina } & HPV type 16 & & [8] \\
\hline & & HIV types 1 & [8] \\
\hline \multirow{5}{*}{ Skin } & UV-associated skin inflammation & & {$[8,10]$} \\
\hline & & Chronic osteomyelitis & [47] \\
\hline & & HIV types 1 & [8] \\
\hline & & HPV types 5,8 & [8] \\
\hline & & MCV & [48] \\
\hline Melanoma & & UV-associated skin inflammation & [9] \\
\hline Non-melanomatous skin cancer & & Cutaneous HPV types & [48] \\
\hline Central nerve & & $\mathrm{JCV}$ & [49] \\
\hline \multirow{2}{*}{ Endothelium (Kaposi's sarcoma) } & HIV type 1 & & {$[8,10]$} \\
\hline & KSHV & & {$[8]$} \\
\hline Vasculature & & Bartonella & [50] \\
\hline \multirow{2}{*}{ Hodgkin's lymphoma } & & EBV & [12] \\
\hline & & HIV type 1 & [51] \\
\hline \multirow{4}{*}{ Non-Hodgkin lymphoma } & & EBV & [12] \\
\hline & & HBV & [52] \\
\hline & & $\mathrm{HCV}$ & [12] \\
\hline & & HTLV-1 & [12] \\
\hline \multirow{12}{*}{ Lymphoma } & EBV & & {$[8,10]$} \\
\hline & $\mathrm{HCV}$ & & [8] \\
\hline & HIV type 1 & & [8] \\
\hline & HTLV-1 & & {$[8,10]$} \\
\hline & KSHV & & [8] \\
\hline & & HIV type 2 & [53] \\
\hline & & Hashimoto's thyroiditis & [9] \\
\hline & & Sjögren's syndrome & [9] \\
\hline & & Childhood celiac disease & [54] \\
\hline & & HBV & [55] \\
\hline & & HTLV-1 & [56] \\
\hline & & Malaria & [10] \\
\hline Orbital lymphoma & & Chlamydia psittaci & [57] \\
\hline Thyroid lymphoma & & Hashimoto's thyroiditis & [58] \\
\hline Lymphoma in the pleural cavity & & EBV & [59] \\
\hline Pyothorax-associated lymphoma & & EBV & [60] \\
\hline MALT lymphoma & Helicobacter pylori & & {$[8,12]$} \\
\hline Small-bowel lymphoma & & Campylobacter jejuni & [61] \\
\hline Cutaneous lymphoma & & Borrelia burgdorferi & [62] \\
\hline DLBC lymphoma & & Helicobacter pylori & [12] \\
\hline Adult T-cell leukemia & ATL (HTLV-1) & & [63] \\
\hline T-cell lymphoma & & EBV & [64] \\
\hline Burkitt's lymphoma & EBV & & [65] \\
\hline B-cell lymphoma & & EBV & [66] \\
\hline Primary effusion lymphoma & & KSHV & [67] \\
\hline
\end{tabular}

ATL, adult T-cell leukemia; COPD, chronic obstructive pulmonary disease; DLBC, diffuse large B-cell; EBV, Epstein-Barr virus; HBV, hepatitis B virus; HCV, hepatitis C virus; HDV, hepatitis D virus; HERV-K, human endogenous retrovirus type K; HIV, human immunodeficiency virus; HPV, human papillomavirus; HTLV-1, human T-cell lymphotropic virus type 1; JCV, JC virus; KSHV, Kaposi sarcoma herpes virus; MALT, mucosa-associated lymphoid tissue; MCV, Molluscum contagiosum virus; UV, ultraviolet. 
Chronic inflammation increases the risk of human cancers of almost all organs/tissues (Figure 1); however, some chronic inflammatory conditions (e.g., psoriasis and rheumatoid arthritis) are not associated with cancers. Figure 2a,b shows infection by viruses, bacteria and parasites as a percentage of all of the causes of inflammation-related cancers; this percentage is $81 \%$ for definitely carcinogenic agents and $64 \%$ for presumed carcinogenic agents. Readers should refer to other review articles for comprehensive information regarding viral, bacterial or parasitic infection-induced cancers [68-70]. It has recently been realized that inhalation of airborne particles (foreign body) is a novel cause of cancer. Here, we focus on this new cause of cancer, i.e., foreign body-induced carcinogenesis.

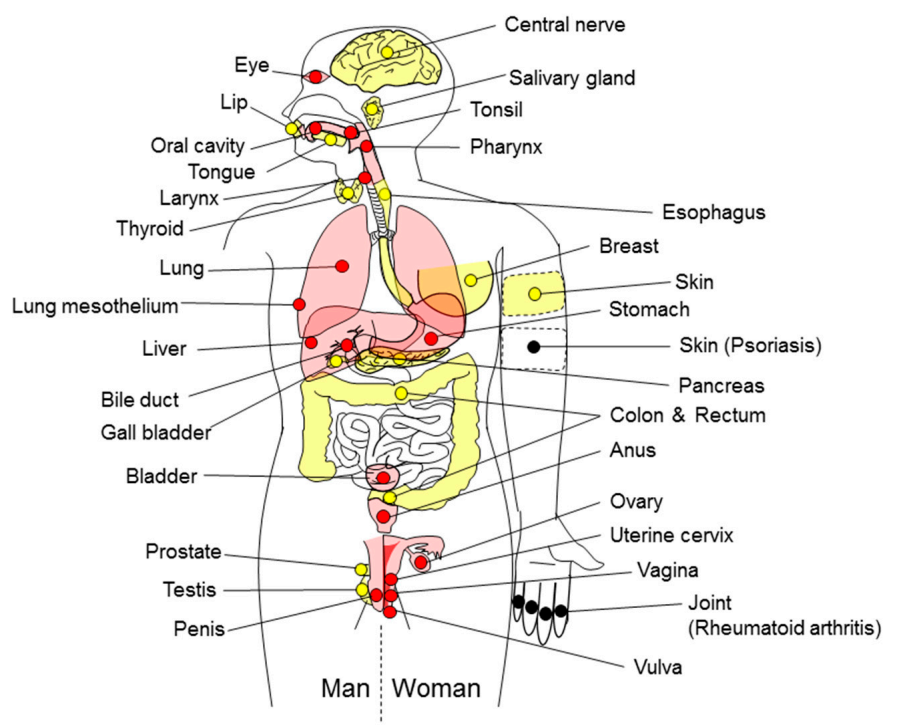

Figure 1. Organs/tissues involved in inflammation-related cancers. The organs/tissues with inflammation induced by definitely carcinogenic agents (red circles) or by presumed carcinogenic agents (yellow circles) are sensitive to cancer development. Skin (psoriasis) and joint (rheumatoid arthritis), indicated by black circles, are resistant to inflammation-related carcinogenesis.

(a)
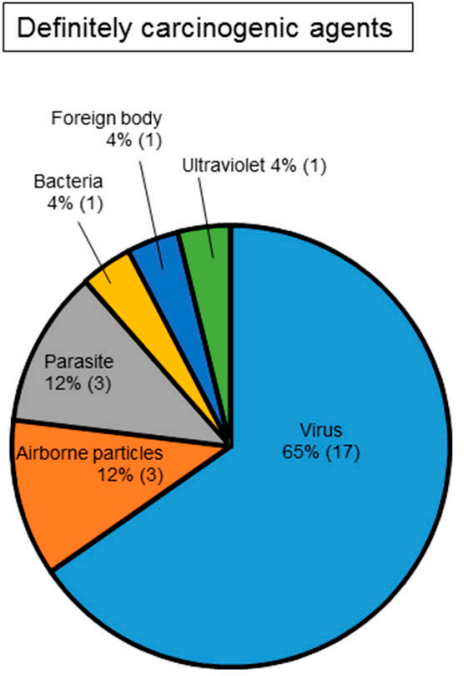

(b)

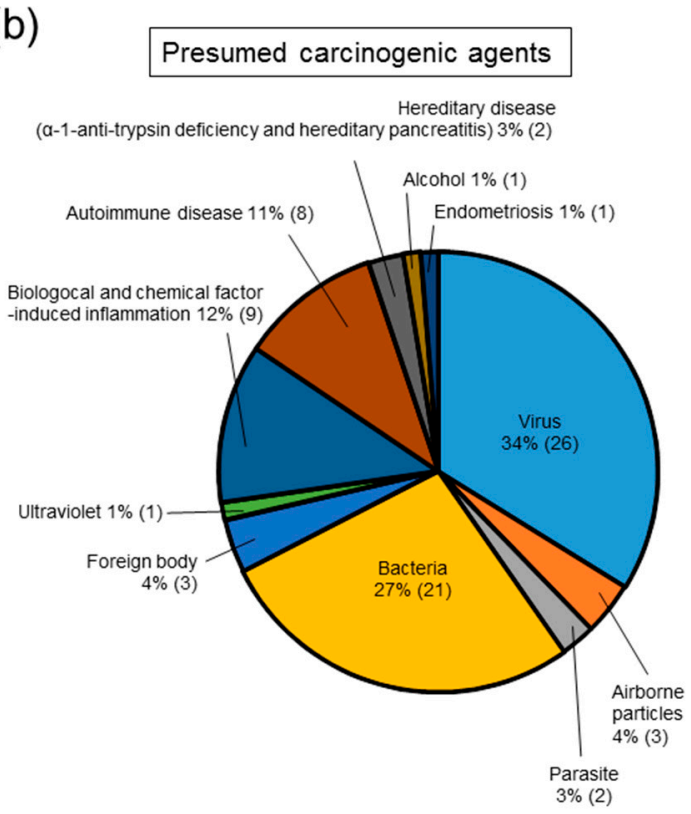

Figure 2. Causes of inflammation-related carcinogenesis. The proportion of definitely carcinogenic causes (a) or presumed carcinogenic causes $(\mathbf{b})$ attributed to inflammation was derived from Table 1. 


\section{Inhaled Foreign Body-Induced Carcinogenesis}

A well-known carcinogenic foreign body is inhaled asbestos fibers, which are associated with mesothelioma and lung cancer (Table 1). The word "asbestos" is of Greek origin, being derived from "a", meaning "not", and "sbestos", meaning "extinguishable". Indeed, macrophages cannot remove the non-digestible asbestos fibers that lead to chronic inflammation [71].

There are three possible mechanisms for asbestos-induced carcinogenesis: (i) through the phenomenon of frustrated phagocytosis in which macrophages fail to phagocytose the long asbestos fibers and die with a massive release of reactive oxygen species (ROS) and pro-inflammatory cytokines that further induce chronic inflammation [72-74]; (ii) through asbestos-associated hemoglobin iron production of ROS via the Fenton reaction. This ROS damages DNA and stimulates the proliferation of alveolar epithelial cells and mesothelial cells [75]; and (iii) through asbestos induction of DNA double-stranded breaks in mesothelial cells, which leads to the promotion of genomic instability [73].

There was a general warning in 1973 that inhalation of asbestos causes lung cancer, gastrointestinal tract cancer and mesotheliomas [71]. The use of asbestos has since been banned in most developed countries; however, China and India still permit its usage [73]. Considering the latent period of mesothelioma (20 to 40 years after the first exposure to asbestos), its incidence is expected to increase further in the countries in which the peak of asbestos use was reached after the 1970s [71].

Not only manufactured products such as asbestos, but also airborne particles induce cancer. PM2.5 (particles with a diameter of $2.5 \mu \mathrm{m}$ or less) can penetrate deeply into the lung, irritate and corrode the alveolar wall and lead to neutrophil infiltration [76]. Additionally, such gaseous particles were shown to decrease pulmonary function in schoolchildren [77]. This effect was caused by their induction of the overproduction of interleukin (IL)-8, an inflammatory cytokine [78]. Asian dust (AD) originates in China and transports a large amount of particulate matter to East Asian countries, such as Korea and Japan. In these countries, exposure to $\mathrm{AD}$ is associated with a decrease in the pulmonary function of adult patients with asthma or with asthma-chronic obstructive pulmonary disease (COPD) overlap syndrome [79]. The mechanisms of the toxicity of PM2.5 towards the respiratory system have been investigated. These studies show that the environmental particle itself acts as a chronic inflammatory agent due to its low clearance rate and high deposition efficiency. In addition, the PM2.5 surface is rich in metals including ferrous iron, copper, zinc and manganese, as well as in polycyclic aromatic hydrocarbons and lipopolysaccharide, which are derived from power generation, industrial activity and biomass burning. These components can induce an inflammatory reaction [76]. An epidemiological study indicated that each $10 \mu \mathrm{g} / \mathrm{m}^{3}$ increase in PM2.5 was associated with a 19-30\% increase in lung cancer mortality (Table 1) [80]. Considering the cross-border nature of airborne particles, international efforts to improve air quality are needed.

Air pollutants also originate from domestic heating and cooking with poor ventilation [16]. Cigarette smoke is another common air pollutant, as well as a foreign body. Smoking is the primary risk factor for COPD, which is characterized by chronic lung inflammation [81]. The presence of COPD is associated with six-times the risk for the development of lung cancer compared to smokers without COPD, indicating that COPD is an independent risk factor for lung cancer (Table 1) [82].

\section{Animal Models for Inflammation-Related Cancer Chemoprevention Studies}

Chemoprevention is the use of pharmacological or natural agents that inhibit or delay the development of cancer [83]. Various animal models that resemble human inflammation-related cancers have been previously generated by genetic engineering or by bacterial/chemical induction, and cancer prevention research has been facilitated by the use of those models (Table 2). We review these animal models in this section. 
Table 2. Animal models for inflammation-related carcinogenesis aimed at the development of chemoprevention.

\begin{tabular}{ccccc}
\hline Treatment & Carcinogen & Animal & Arising Tumor & Reference \\
\hline Esophagojejunostomy & None & Rat & Esophageal adenocarcinoma & {$[84]$} \\
\hline H. pylori infection & MNNG & Mongolian gerbil & Gastric adenocarcinoma & {$[85]$} \\
\hline DSS & None & Mouse & Colorectal adenocarcinoma & {$[86]$} \\
\hline DSS & AOM & Mouse & Colorectal adenocarcinoma & {$[86]$} \\
\hline DSS & DMH & Mouse & Colorectal adenocarcinoma & {$[87]$} \\
\hline DSS & PhIP & Mouse & Colorectal adenocarcinoma & {$[86]$} \\
\hline DSS & None & Apc Min/+ mouse $^{\text {Colorectal adenocarcinoma }}$ & {$[87]$} \\
\hline None & None & $\begin{array}{c}\text { HBV-transgenic } \\
\text { mouse }\end{array}$ & Hepatocellular carcinoma & {$[88]$} \\
\hline None & DEN & Rat & Hepatocellular carcinoma & {$[89]$} \\
\hline CCl ${ }_{4}$ & DEN & Mouse & Hepatocellular carcinoma & {$[90]$} \\
\hline O. viverrini infection & NDMA & Hamster & Cholangiocarcinoma & {$[91]$} \\
\hline \multirow{2}{*}{ Choledochojejunostomy } & $\begin{array}{c}\text { N-nitrosobis(2- } \\
\text { oxopropyl)amine }\end{array}$ & Hamster & Biliary carcinoma & {$[92]$} \\
\hline Caerulein & None & K-ras mutated & Pancreatic ductal & {$[93]$} \\
\hline TPA & DMBA & Mouse & Squamous cell carcinoma & {$[94]$} \\
\hline
\end{tabular}

AOM, Azoxymethane; Apc, adenomatous polyposis coli; $\mathrm{CCl}_{4}$, carbon tetra chloride; DEN, diethylnitrosamine; DMBA, 7,12-dimethylbenz[a]-anthracene; DMH, dimethylhydrazine; DSS, dextran sulfate sodium; HBV, hepatitis B virus; H. pylori, Helicobacter pylori; MNNG, N-methyl- $N^{\prime}$-nitro- $N$-nitrosoguanidine; NDMA, N-nitrosodimethylamine; O. viverrini, Opisthorchis viverrini; PhIP, 2-amino-1-methyl-6-phenylimidazo[4,5-b] pyridine; TPA, 12-O-tetradecanoylphorbol-13-acetate.

\subsection{Esophageal Cancer}

The rat model for esophago-duodenal anastomosis is known to sequentially progress from reflux esophagitis to Barrett's esophagus and then to esophageal adenocarcinoma within 50 weeks of the operation [84]. Mouse reflux models yield a lower incidence of adenocarcinoma (7\%) compared to rat models (40\%) [95-97]. The rat reflux model is therefore widely used for the exploration of chemopreventive agents.

\subsection{Gastric Cancer}

Transgenic mice that overexpressed human gastrin and were infected with Helicobacter pylori (H. pylori) uniformly developed gastric adenocarcinoma by 24 weeks [98]. However, there have been no descriptions of non-genetically engineered mice that have developed gastric adenocarcinoma, which is probably a reflection of poor host adaptation to H. pylori [99]. Helicobacter felis (H. felis) isolated from the feline stomach can colonize the murine stomach similar to $H$. pylori and sequentially induce chronic gastritis, atrophy, intestinal metaplasia and adenocarcinoma $[99,100]$. However, unlike H. pylori infection of humans, neutrophil infiltration is less prominent in $H$. felis-induced murine gastritis, and H. felis is deficient in the production of the Helicobacter cytotoxin, vacA and the pro-inflammatory cytokine inducer, cagA $[99,101]$. Mice infected with $H$. pylori have a low susceptibility to gastric carcinogenesis even when a chemical carcinogen is used [102]. Besides these mouse models, a Mongolian gerbil was successfully established to mimic human $H$. pylori infection and chronic inflammation, in which the bacteria were detectable throughout the one-year study period [100]. Gastric adenocarcinomas that are very similar to those in humans were developed in $64 \%$ of $H$. pylori-infected Mongolian gerbils treated with $N$-methyl- $N^{\prime}$-nitro- $N$-nitrosoguanidine at Week 50 [85].

\subsection{Colon Cancer}

Oral administration of dextran sulfate sodium (DSS) is well known to induce colitis in animals. DSS causes defects in epithelial barrier integrity, thereby enhancing colonic mucosal permeability 
to allow the entry of luminal antigens and bacteria into the mucosa, resulting in an inflammatory response [103]. Repeated administration of DSS that mimics acute and chronic phases of human ulcerative colitis induces chronic inflammation that is characterized by severe tissue injury of both the lamina propria and submucosa [103-105]. The use of DSS in combination with intraperitoneal injection of azoxymethane (AOM), a chemical carcinogen, results in $100 \%$ incidence of colonic tumors, whereas the incidence is only $13 \%$ to $19 \%$ when DSS is administered alone [86]. The incidence of neoplasia is also increased by administration of DSS in combination with other carcinogens, such as dimethylhydrazine (DMH) or 2-amino-1-methyl-6-phenylimidazo[4,5-b] pyridine [86,87].

Genetically-modified animal models of colon cancer have been generated. For example, the $A p c^{\mathrm{Min} /+}$ mouse carries a germline mutation that converts codon 850 of the murine Adenomatous polyposis coli $(A p c)$ gene from a leucine to a stop codon [106] and that mimics the development of adenomatous polyps in humans with familial adenomatous polyposis (FAP). However, the most common sites of tumors of $A p c^{\mathrm{Min} /+}$ mice is the small intestine [87]. Apc $c^{\mathrm{Min} /+}$ mice exhibited adenomas in the small intestine at the age of five weeks [107] and subsequently developed intestinal adenomas (100\% incidence). In the colon, precancerous lesions such as aberrant crypt foci or $\beta$-catenin accumulated crypts are observed, but the incidence of adenocarcinoma is no more than about $20 \%$ [108]. DSS administration to $A p c^{\mathrm{Min} /+}$ mice leads to colonic adenocarcinoma formation in all cases $[87,108]$. Since $A p c^{\mathrm{Min} /+}$ mice are $A p c$ gene hetero-deficient, they are already in the initiated phase of tumor development. Therefore, DSS-induced inflammation acts as a promoter for colonic adenocarcinoma development [87].

\subsection{Hepatocellular Carcinoma}

Reliable methods to induce chronic inflammation-related hepatocellular carcinoma (HCC) in rodents are the use of chemicals or of transgenic approaches.

Hepatitis B or C viruses (HBV or HCV) can infect human hepatocytes subsequently leading to chronic inflammation and HCC development. In contrast to humans, mice are resistant to infection with HBV and HCV [109]. Transgenic mice carrying the full HBV genome except for the core protein were initially developed to model chronic HBV infection; however, HCC did not develop [110]. After this first report in 1985, transgenic mice overexpressing the HBV surface antigen in hepatocytes were established. This model exhibits chronic inflammation with necrosis, which inevitably leads to HCC [88].

Fourteen kinds of transgenic mice carrying HCV genes, such as the HCV polyprotein, and core protein alone or in combination with envelope proteins have been previously generated [109]. However, these HCV infection models either developed HCC without inflammation or did not form carcinomas [111]. Considering that there are no mouse models for hepatitis C-associated chronic inflammation-induced HCC, HBV transgenic mice are suitable as a mouse model that mimics the chronic carrier state of cancer-prone hepatitis virus infection.

Chemical carcinogens are also widely used to initiate hepatocarcinogenesis in animals. Diethylnitrosamine (DEN) was found to induce HCC in rodents in 1966 [112]. DEN is converted into a DNA alkylating agent by cytochrome $\mathrm{P} 450$ of hepatocytes and acts as a complete carcinogen if intraperitoneally injected into two-week-old mice [109]. The metabolic activation of DEN also generates ROS [109]. However, single injection of DEN results in carcinoma formation without cirrhosis. Therefore, the pathological process of the DEN-elicited rodent HCC is different from that of human HCC. In 2005, a rat model of DEN-induced liver injury that reproduces the sequence of cirrhosis and HCC that is observed in humans was established [89]. Once-a-week intraperitoneal injection of DEN for 16 weeks causes cirrhosis and multifocal HCC in all rats, similar to the case in human HCC [89].

Intraperitoneal injection of carbon tetrachloride $\left(\mathrm{CCl}_{4}\right)$ induces pericentral necrosis of hepatocytes and inflammatory cell infiltration. In $\mathrm{CCl}_{4}$ treatment alone, only $25 \%$ of mice showed HCC [90]. 
In contrast, HCC was found in 50\% of mice when a single injection of DEN, functioning as a tumor initiator, was followed by repeat treatment with $\mathrm{CCl}_{4}$, used as a tumor promoter, for 14 weeks.

\subsection{Cholangiocarcinoma}

Syrian golden hamsters infested with the liver fluke, Opisthorchis viverrini (O. viverrini), have been used as a model for cholangiocarcinoma. Infestation of the liver fluke alone rarely leads to cholangiocarcinoma. However, $100 \%$ incidence of bile duct cancers resembling those seen in humans resulted from the infestation prior to administration of $N$-nitrosodimethylamine (NDMA) [91]. The effect of liver fluke infestation and NDMA dose on the development of bile duct cancer is synergistic [113], indicating that there are several mechanisms underlying infestation-related carcinogenesis [114]. Firstly, the presence of the parasite mechanically damages bile duct epithelial cells that have a mutation that is caused by the carcinogen, resulting in increased cell proliferation, which fixes the DNA mutation $[115,116]$. Secondary, ROS and nitric oxide (NO) released by inflammatory cells cause DNA damage [114,117]. The third possibility is that inflammatory cells produce pro-inflammatory cytokines [114]. A fourth possible explanation is that O. viverrini secretes exosomes, one kind of membrane vesicle containing proteins, mRNA, miRNAs and DNAs [118], to promote cholangiocyte proliferation and IL-6 production [119].

\subsection{Biliary Tract Cancer}

Pancreaticobiliary maljunction (PBM) is characterized by abnormal fusion of the pancreatic and biliary ducts [120]. A PBM model was developed using the Syrian golden hamster [121]. Cholecystoduodenostomy in hamsters causes reflux of pancreatic juice into the biliary tract; as a result, pancreatic enzymes and secondary bile acid induce chronic inflammation with injury to biliary epithelia [122]. Biliary tract cancer developed in $41 \%$ to $82 \%$ of $N$-nitrosobis(2-oxopropyl)amine subcutaneously-injected hamsters after cholecystoduodenostomy [92].

\subsection{Pancreatic Ductal Adenocarcinoma}

Approximately $90 \%$ of human pancreatic ductal adenocarcinomas (PDAC) harbor mutations in codon 12, 13 or 61 of the K-ras gene [123,124], suggesting that K-ras is a driver gene in PDAC. However, only $50 \%$ of transgenic mice carrying a mutation of codon 12 of the K-ras allele (K-ras-mutated mice) developed PDAC [93]. When caerulein, an inducer of pancreatitis, was intraperitoneally-injected into K-ras-mutated mice constantly for six months, all of the mice had PDAC [93]. This result shows that chronic pancreatitis is necessary for the induction of PDAC and that K-ras mutation alone is insufficient for pancreatic carcinogenesis.

\subsection{Skin Cancer}

Two-stage skin carcinogenesis was developed in the 1940s. In the first stage, initiation occurs following a single administration of 7,12-dimethylbenz[a]-anthracene (DMBA). In the second stage, benign papillomas and/or invasive squamous cell carcinomas (SCC) developed by repeated treatment with 12-O-tetradecanoylphorbol-13-acetate (TPA), an inflammatory agent, to the initiated skin [94]. The DMBA/TPA skin model is used for screening of cancer chemopreventive compounds [125]. DMBA generates a point mutation in Ha-ras. TPA stimulates inflammation and the proliferation of Ha-ras-mutated cells [94]. Papillomas developed in about $80 \%$ of the mice by 22 weeks after initiation; the frequency of conversion of papilloma to carcinoma was about $20 \%$ at Week 32 [126]. A whole-exome sequencing study showed that $18 \%$ to $44 \%$ of the genes in DMBA/TPA-induced SCC, including Ha-ras, K-ras and p53, overlapped with genes in human SCC [127]. The DMBA/TPA skin tumor model therefore mimics human skin carcinogenesis at the genetic level. 


\subsection{Experimental Models of Foreign Body-Induced Carcinogenesis}

In addition to infection, administration of a chemical substance or implantation of a foreign body also induces inflammation-related carcinogenesis. The first experimental evidence for a foreign body-induced tumor was reported in 1941 [71]. Most animal models of foreign body-induced tumorigenesis do not require a chemical carcinogen.

For example, 79\% heterozygous $p 53$-deficient $\left(p 53^{+/-}\right)$mice developed spontaneous sarcomas via induction of $p 53$ loss of heterozygosity at a mean time of 35 weeks after a piece of plastic plate $(1 \mathrm{~mm} \times 5 \mathrm{~mm} \times 10 \mathrm{~mm}$, polystyrene, used as a culture dish) was subcutaneously implanted [128]. Thus, an inflammatory reaction against a foreign body is sufficient for tumorigenesis. The carcinogenic potential of a foreign body depends on its properties [71]. Solid, smooth and large foreign bodies are more potent inducers of chronic inflammation than more roughened, smoothened and smaller ones [129]. As examples of foreign body-induced tumors, human or rodent immortalized cell lines that had been implanted attached to a plastic plate or a glass bead into mice or rats grew progressively in $8 \%$ to $100 \%$ of animals regardless of the origin of the cell (species, epithelial or non-epithelial cells) [71]. Another approach to establish this model is by using regressive tumors or precancerous cells.

FPCK-1-1 cells that are derived from a colonic polyp of a patient with FAP are non-tumorigenic when injected subcutaneously into nude mice. However, when these cells were attached to a piece of plastic plate and implanted into a subcutaneous space, the cells spontaneously converted into progressively-growing, moderately-differentiated adenocarcinoma cells in $65 \%$ of the mice [130]. The plastic plate initially induces acute inflammation, which then transitions to chronic inflammation [130]. A highly proliferative fibrous stroma composed mainly of fibroblasts was formed 120 days after plastic plate implantation. When FPCK-1-1 cells were injected into stromal tissues that were surrounded by a plastic plate, they converted into adenocarcinoma cells [130]. This result showed that the malignant conversion of FPCK-1-1 cells occurred not due to the plastic plate itself, but due to the plastic plate-induced fibrous stroma. NO derived from a chronically-inflamed lesion caused the conversion of FPCK-1-1 cells [131]. Moreover, the actin-filament bundling protein fascin-1 was found to be a suppressor of anoikis (apoptotic cell death as a consequence of insufficient cell-to-substrate interactions) and to drive the malignant conversion of FPCK-1-1 cells [132]. This malignant conversion seldom occurs in adenoma cells in the presence of a gelatin sponge, which is spontaneously absorbed in a short period and thus induces only the early phase of inflammation, indicating that the conversion requires chronic inflammation [130]. It should be noted that the carcinogenic inflammation was not induced in colon tissue, which is an orthotopic site for colon carcinogenesis, but in a subcutaneous space, which is an ectopic site. This evidence indicates that causes or sites of inflammation do not account for colon carcinogenesis, but that long-standing inflammation is necessary for colon carcinogenesis [130].

We have introduced chronic inflammation as a common cause of inflammation-related cancers in this review. However, acute inflammation also induces tumor formation experimentally. QR-32 cells (a mouse fibrosarcoma clone) regressed spontaneously after injection into syngeneic C57BL/6 mice, but could grow indefinitely in vitro [133]. Subcutaneous implantation of a gelatin sponge $(3 \mathrm{~mm} \times 5 \mathrm{~mm} \times 10 \mathrm{~mm}$ ) induces inflammatory cell (mainly neutrophils) infiltration. As mentioned above, the sponge is naturally absorbed about four weeks after implantation, and therefore, transition from acute to chronic inflammation is unlikely to occur when using a sponge [71]. The regressive QR-32 cells become tumorigenic after implantation into a pre-inserted piece of sponge. Moreover, the sponge-infiltrated inflammatory cells convert QR-32 cells into tumorigenic cells when both cells are mixed and injected subcutaneously [133]. Elimination of neutrophils by administration of an anti-neutrophil antibody inhibited the acquisition of malignant phenotype by QR-32 cells [134]. These findings show that neutrophil infiltration is needed for inflammation-related carcinogenesis $[133,134]$. There are advantages in using a gelatin sponge for investigating inflammation-related carcinogenesis. Since sponge-infiltrated inflammatory cells can be collected by treating the sponge with collagenase, 
it is possible to quantify the number of infiltrated cells, determine the cell types and analyze the molecular expression profiles of the inflammatory reaction [135].

\section{Ten Mechanisms Involved in Inflammation-Related Carcinogenesis-Based Chemoprevention}

Cancer prevention is the ultimate goal of inflammation-related carcinogenesis research. Chemoprevention research by using animal models of inflammation-related carcinogenesis as described above started in the late 1990s and continues to this day.

Chemopreventive agents act through a combination of various mechanisms. By the study of these mechanisms of action, we summarized 10 mechanisms that are involved in the promotion of inflammation-related cancer development. These mechanisms are: (i) inflammatory cell infiltration; (ii) ROS; (iii) NO; (iv) reduction of antioxidant enzymes; (v) reduction of antioxidants; (vi) activation of $\mathrm{NF}-\mathrm{kB}$; (vii) upregulation of pro-inflammatory cytokines; (viii) downregulation of anti-inflammatory cytokines; (ix) elevation of chemokines; and (x) induction of cyclooxygenase (COX)-2 (Figure 3).

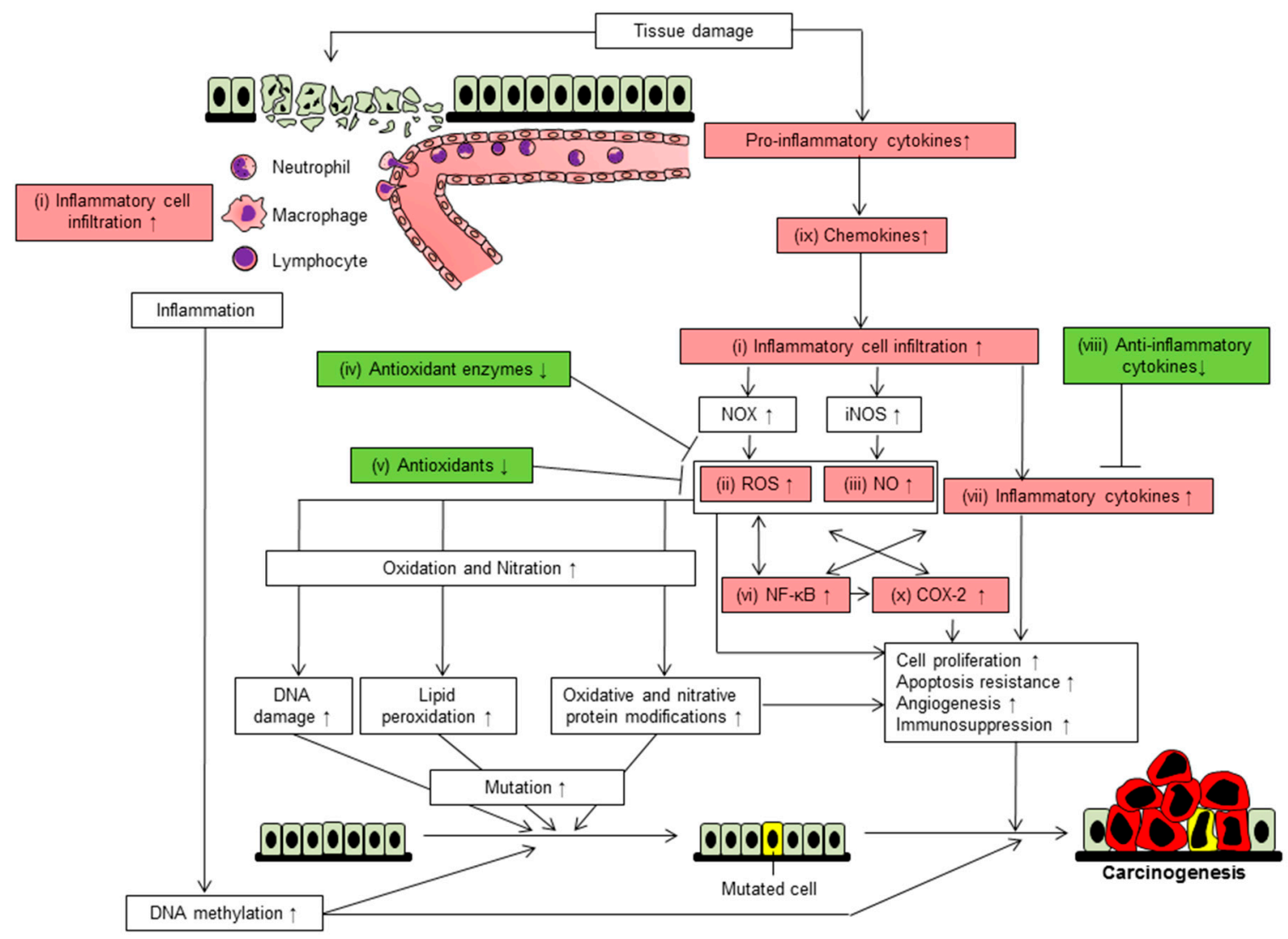

Figure 3. Schematic mechanism of inflammation-induced cancer development. Tissue damage causes inflammatory cell infiltration (i). Leukocytes produce ROS (ii) and NO (iii) resulting in oxidative/nitrative stress (DNA damage, lipid peroxidation, protein modification and, thus, mutation). Reduction of antioxidant enzymes (iv) and antioxidants (v), which scavenge ROS, leads to enhancement of oxidative stress. A positive feedback loop between NF- $\mathrm{BB}$ (vi) and pro-inflammatory cytokines (vii) is necessary for inflammation to become chronic. Anti-inflammatory cytokines (viii) are downregulated in inflammation-related carcinogenesis. Chemokines (ix) recruit leukocytes into inflammatory sites. In addition to ROS, NO and pro-inflammatory cytokines, COX-2 (x) promotes cell proliferation and angiogenesis and suppresses apoptosis and immunosurveillance. Inflammation also causes DNA methylation, which results in aberrant gene expression. Ten possible chemopreventive targets are shown in the red boxes. Factors that are decreased are shown in the green boxes. Pointed arrows indicate promotion/activation while T-shaped arrows indicate suppression. 


\subsection{Inflammatory Cell Infiltration}

Tissue injury caused by factors such as infection or a foreign body induces the sequential infiltration of neutrophils and monocytes (Figure 3). Granulocyte macrophage colony-stimulating factor released from epithelial cells or fibroblasts induces the differentiation of monocytes into M1 macrophages [136]. IL-4 works with macrophage colony-stimulating factor to induce to M2 macrophage polarization [137]. Tumor-associated macrophages (M2-like macrophages) promote inflammation-related carcinogenesis [138]. Infiltrated (activated) neutrophils, but not circulating or bone marrow neutrophils, are involved in carcinogenesis [133,134]. Depletion of macrophages using clodronate inhibited macrophage infiltration, resulting in suppression of AOM/DSS-induced mouse colon carcinogenesis [139]. Therefore, not only neutrophils, but also macrophages are necessary for cancer development in chronic inflammatory conditions. Indeed, the number of myeloperoxidase-positive cells (neutrophils and macrophages) was higher in the colonic mucosa of patients with inflammatory bowel disease (IBD) or its associated cancer than in normal mucosa [140], suggesting that inflammatory cell infiltration also plays a key role in human carcinogenesis.

Chemokines and adhesion molecules function in the recruitment of neutrophils and monocyte into inflammatory sites [141]. Integrin $\beta 2$ is the key adhesion molecule for neutrophil extravasation. C-C motif chemokine receptor (CCR)2 is a specific receptor for the monocyte-tropic chemokine, $\mathrm{C}-\mathrm{C}$ motif chemokine ligand (CCL)2. Genetic deletion of integrin $\beta 2$ or CCR2 inhibited neutrophil/monocyte infiltration and protected mice from inflammation-related carcinogenesis [134,142]. Thus, inhibition of the initial process of inflammation, i.e., the infiltration of inflammatory cells, is a target for the prevention of chronic inflammation and carcinogenesis (Table 3). 
Table 3. Chemopreventive agents against the 10 possible mechanisms of inflammation-related carcinogenesis.

\begin{tabular}{|c|c|c|}
\hline Prevention Strategy & Chemopreventive Agent [Reference] & Type of Agent \\
\hline \multirow{8}{*}{$\begin{array}{l}\text { I. Inhibition of inflammatory } \\
\text { cell infiltration }\end{array}$} & $\begin{array}{l}\text { Apocynin [143], apple oligogalactan [144], FBRA [145], Ganoderma lucidum [146], MEFA [147], } \\
\text { MELA [147], PAG [148], } \gamma \text {-TmT [149] }\end{array}$ & Food product \\
\hline & $\begin{array}{l}\text { Auraptene [150], canolol [151], genistein-27 [152], geraniol [153], inotilone [154], micheliolide } \\
\text { [155], nobiletin [156], tumerone [150], vitamin D [157] }\end{array}$ & Natural compound \\
\hline & Hexaphosphate inositol [158], inositol [158], statin hydroxamate [159] & Low-molecular weight compound \\
\hline & Melatonin [160] & Amino acid and its derivative \\
\hline & Sulindac [161] & COX inhibitor \\
\hline & Cholera-toxin [162] & Protein \\
\hline & Oligonucleotides [163] & Oligonucleotides \\
\hline & 13-HOA [164] & Fatty acid \\
\hline \multirow{4}{*}{ II. Inhibition of ROS } & Juzen-taiho-to [165], oligonol [166], protandim [167] & Food product \\
\hline & $\begin{array}{l}\text { Auraptene [150], benzyl isothiocyanate [168], caffeine [169], crocin [170], DBM [171], } \\
\text { digitoflavone [172], geraniol [153], GOFA/ } \beta-C D \text { [173], menthol [174], organomagnesium } \\
\text { [175], oxykine [176], PEITC [171], PSK [177], silibinin [178], tumerone [150], vitamin E [179], } \\
\text { 3,3-diindolylmethane [180] }\end{array}$ & Natural compound \\
\hline & $\begin{array}{l}\text { Bismuth subnitrate [165], } \\
\text { 3-aroylmethylene-2,3,6,7-tetrahydro-1H-pyrazino[2,1-a]isoquinolin-4(11bH)-ones [181] }\end{array}$ & Low-molecular weight compound \\
\hline & Melatonin [160], N-acetylcysteine [182], selenium [182] & Amino acid and its derivative \\
\hline \multirow{5}{*}{ III. Suppression of iNOS } & EVOO [183], FBRA [184], MEFA [147], MELA [147], oligonol [166], PAG [148] & Food product \\
\hline & $\begin{array}{l}\text { Astaxanthin [185], baicalein [186], betaine [187], canolol [151], crocin [170], curcumin [188], } \\
\text { inotilone [154], nobiletin [156], organomagnesium [175], pterostilbene [189], silibinin [178], } \\
\text { UDCA [190], 5-OH-HxMF [191] }\end{array}$ & Natural compound \\
\hline & $\begin{array}{l}\text { Aminoguanidine [131], bezafibrate [192], GOFA-L-NAME [193], omeprazole [194], } \\
\text { ONO-1714 [195], troglitazone [192] }\end{array}$ & Low-molecular weight compound \\
\hline & Aspirin [196], nimesulide [192] & COX inhibitor \\
\hline & Glutamine [197] & Amino acid and its derivative \\
\hline
\end{tabular}


Table 3. Cont

\begin{tabular}{|c|c|c|}
\hline Prevention Strategy & Chemopreventive Agent [Reference] & Type of Agent \\
\hline \multirow{4}{*}{$\begin{array}{l}\text { IV. Induction of } \\
\text { antioxidant enzymes }\end{array}$} & Juzen-taiho-to [165], oligonol [166], protandim [167] & Food product \\
\hline & $\begin{array}{l}\text { Crocin [170], DBM [171], digitoflavone [172], geraniol [153], GOFA/ } \beta-C D \text { [173], menthol [174], } \\
\text { organomagnesium [175], PEITC [171], PSK [177], 3,3-diindolylmethane [180] }\end{array}$ & Natural compound \\
\hline & $\begin{array}{l}\text { Bismuth subnitrate [165], } \\
\text { 3-aroylmethylene-2,3,6,7-tetrahydro-1H-pyrazino[2,1-a]isoquinolin-4(11bH)-ones [181] }\end{array}$ & Low-molecular weight compound \\
\hline & Melatonin [160] & Amino acid and its derivative \\
\hline \multirow[t]{2}{*}{ V. Antioxidants } & $\begin{array}{l}\text { Auraptene [150], benzyl isothiocyanate [168], caffeine [169], geraniol [153], oxykine [176], silibinin [178], } \\
\text { tumerone [150], vitamin E [179] }\end{array}$ & Natural compound \\
\hline & $N$-acetylcysteine [182], selenium [182] & Amino acid and its derivative \\
\hline \multirow{5}{*}{ VI. Inactivation of NF- $\kappa$ B } & Apple oligogalactan [144], EAPP [198], FBE [199], ME [199], oligonol [166], PAG [148], protandim [167] & Food product \\
\hline & $\begin{array}{l}\text { Astaxanthin [185], baicalein [186], betaine [187], crocin [170], curcumin [188], genistein-27 [152], } \\
\text { GOFA/ } \beta-C D ~[173], \text { inotilone [154], menthol [174], micheliolide [155], pterostilbene [189], silibinin [178], } \\
\text { tricin [200], vitamin D [157], 3,3-diindolylmethane [180], 5-OH-HxMF [191] }\end{array}$ & Natural compound \\
\hline & Cerulenin [201] & Low-molecular weight compound \\
\hline & Glutamine [197], melatonin [160] & Amino acid and its derivative \\
\hline & MiR-214 chemical inhibitor [202] & Oligonucleotides \\
\hline \multirow{8}{*}{$\begin{array}{l}\text { VII. Downregulation of } \\
\text { pro-inflammatory cytokines }\end{array}$} & $\begin{array}{l}\text { Apple oligogalactan [144], EVOO [183], FBRA [145], Ganoderma lucidum [146], MEFA [147], MELA [147], } \\
\text { oligonol [166] }\end{array}$ & Food product \\
\hline & $\begin{array}{l}\text { Astaxanthin [185], betaine [187], canolol [151], crocin [170], curcumin [188], digitoflavone [172], } \\
\text { genistein-27 [152], GOFA/ } \beta-C D \text { [173], isoliquiritigenin [139], micheliolide [155], organomagnesium } \\
\text { [175], oroxylin A [203], pterostilbene [189], silibinin [178], tricin [200], triptolide [204], resveratrol [205], } \\
\text { UDCA [190], vitamin D [157] }\end{array}$ & Natural compound \\
\hline & $\begin{array}{l}\text { Cerulenin [201], GOFA-L-NAME [193], NT1014 [206], omeprazole [194], statin hydroxamate [159], } \\
\text { 3-aroylmethylene-2,3,6,7-tetrahydro-1H-pyrazino[2,1-a]isoquinolin-4(11bH)-ones [181], 5-aza-dC [207] }\end{array}$ & Low-molecular weight compound \\
\hline & Glutamine [197], melatonin [160] & Amino acid and its derivative \\
\hline & Aspirin [196] & COX inhibitor \\
\hline & Cholera-toxin [162], $\alpha$-lactalbumin [208] & Protein \\
\hline & Oligonucleotides [163] & Oligonucleotides \\
\hline & Eicosapentaenoic acid-free fatty acid [209] & Fatty acid \\
\hline
\end{tabular}


Table 3. Cont.

\begin{tabular}{|c|c|c|}
\hline Prevention Strategy & Chemopreventive Agent [Reference] & Type of Agent \\
\hline \multirow{2}{*}{$\begin{array}{l}\text { VIII. Upregulation of } \\
\text { anti-inflammatory cytokines }\end{array}$} & PSK [177] & Natural compound \\
\hline & Cholera-toxin [162] & Protein \\
\hline \multirow{5}{*}{$\begin{array}{l}\text { IX. Downregulation of } \\
\text { chemokines }\end{array}$} & FBRA [145] & Food product \\
\hline & Auraptene [150], tumerone [150], vitamin D [157] & Natural compound \\
\hline & Statin hydroxamate [159] & Low-molecular weight compound \\
\hline & Glutamine [197] & Amino acid and its derivative \\
\hline & Oligonucleotides [163] & Oligonucleotides \\
\hline \multirow{8}{*}{ X. Inhibition of COX-2 } & $\begin{array}{l}\text { EVOO [183], FBRA [184], Ganoderma lucidum [146], MEFA [147], MELA [147], oligonol [166], PAG } \\
\text { [148], } \gamma \text {-TmT [149] }\end{array}$ & Food product \\
\hline & $\begin{array}{l}\text { Astaxanthin [185], betaine [187], canolol [151], crocin [170], curcumin [188], geraniol [153], inotilone } \\
\text { [154], isoliquiritigenin [139], menthol [174], nobiletin [156], organomagnesium [175], pterostilbene } \\
\text { [189], resveratrol [205], silibinin [178], 3,3-diindolylmethane [180], 5-OH-HxMF [191] }\end{array}$ & Natural compound \\
\hline & $\begin{array}{l}\text { Bezafibrate [192], cerulenin [201], GOFA-L-NAME [193], omeprazole [194], statin hydroxamate [159], } \\
\text { troglitazone [192] }\end{array}$ & Low-molecular weight compound \\
\hline & Glutamine [197], melatonin [160] & Amino acid and its derivative \\
\hline & Aspirin [196], celecoxib [210], MF-tricyclic [211], nimesulide [192], sulindac [161] & COX inhibitor \\
\hline & $\alpha$-lactalbumin [208] & Protein \\
\hline & Oligonucleotides [163] & Oligonucleotides \\
\hline & Eicosapentaenoic acid-free fatty acid [209] & Fatty acid \\
\hline
\end{tabular}

COX-2, cyclooxygenase-2; DBM, dibenzoylmethane; EAPP, ethanol extracts from the aerial parts of A. princeps Pampanini cv. Sajabal; EVOO, extra virgin olive oil; FBE, fruiting body extract; FBRA, fermented brown rice and rice bran with Aspergillus oryzae; GOFA-L-NAME, $4^{\prime}$-geranyloxyferulic acid- $N$ (omega)-nitro-L-arginine methyl ester; GOFA/ $\beta$-CD, 3-(4'-geranyloxy-3'-methoxyphenyl)-2-trans propenoic acid/ $\beta$-cyclodextrin; iNOS, inducible nitric oxide synthase; ME, mycelia extract; MEFA, methanol extracts of the fruit of $A$. communis; MELA, methanol extract of the leaf of A. communis; miR, microRNA; $\gamma$-TmT, $\gamma$-tocopherol-rich mixture of tocopherols; PAG, processed Aloe vera gel; PEITC, phenethyl isothiocyanate; PSK, polysaccharide K; ROS, reactive oxygen species; UDCA, ursodeoxycholic acid; 13-HOA, ( \pm -13-hydroxy-10-oxo-trans-11-octadecenoic acid; 5-OH-HxMF, 5-hydroxy-3,6,7,8,3', $4^{\prime}$-hexamethoxyflavone. 


\subsection{Reactive Oxygen Species}

Oxidative stress can lead to mutations and increased cell proliferation, and therefore, it plays a crucial role in inflammation-related carcinogenesis.

High ROS accumulation results in oxidative damage to DNA, protein or lipids, while a small increase in ROS acts as a growth signaling molecule in both normal and cancer cells [212]. Moreover, ROS is mutagenic across species [213]. In acute inflammation, the infiltrated inflammatory cells generate a massive amount of ROS to kill the invading pathogens $[214,215]$. If the acute inflammatory response fails to eliminate the pathogens and the inflammatory process persists, the sustained overproduction of ROS induces DNA damage and the proliferation of normal cells, which are associated with an increased risk of neoplastic transformation [214].

The bactericidal function of phagocytes including neutrophils depends on the generation of superoxide from the NADPH oxidase complex, which consists of cytosolic proteins (gp40 phox , gp $47^{\text {phox }}$, gp6 $7^{\text {phox }}$ and Rac) and a membrane-bound complex carrying cytochrome $b_{558}$ (gp91 ${ }^{\text {phox }}$, the catalytic core of phagocyte NADPH oxidase and gp22 $2^{\text {phox }}$ ) [216,217]. In gp91 phox-/- mice, inflammation-related tumor development and metastasis were suppressed. Adoptively-transferred wild-type-derived infiltrated phagocytes into gp91 $91^{\text {phox- } /-}$ mice recovered the acquisition of tumorigenicity and metastatic potential [218].

ROS further generates other reactive species (e.g., malondialdehydes (MDA) and 4-hydroxynonenal (4-HNE)) through lipid peroxidation. MDA and 4-HNE induce point mutation of the proto-oncogene K-ras and the tumor suppresser gene $p 53$ (Figure 3), thereby acting as a driving force for malignancy in chronic pancreatitis and IBD [219].

\subsection{Nitric Oxide}

NO is also released from infiltrated cells in chronic inflammatory tissues and causes alterations in DNA. NO is involved in colon cancer [220] and esophageal cancer [221] associated with inflammation. The main mechanisms of ROS and NO in inflammation-related carcinogenesis are DNA base modifications and strand breaks resulting in DNA-replication errors and genomic instability (Figure 3) [214]. There are at least two mechanism of NO-mediated carcinogenesis. First, NO converts colonic adenoma cells to adenocarcinoma cells by inducing the acquisition of resistance to anoikis [131]. Second, NO inactivates DNA repair enzymes and p53 proteins via post-translational modifications, such as nitrosylation, nitration and deamination (Figure 3) [222].

\subsection{Reduction of Antioxidant Enzymes}

The ROS level is determined by the rates of both ROS production and of ROS scavenging [212]. Therefore, suppression of the ROS production system or promotion of ROS scavenging activity is an effective strategy to prevent carcinogenesis.

In an experimental inflammation-related tumorigenesis model, an inverse correlation was observed between the frequency of inflammatory cell-induced somatic mutation or tumor formation and the activity of intracellular antioxidant enzymes (manganese superoxide dismutase (Mn-SOD) and glutathione peroxidase) [223]. Moreover, treatment with polysaccharide K [177] or an orally-available SOD [176] suppressed inflammation-related tumorigenesis by increasing Mn-SOD via induction of inflammatory cytokines.

\subsection{Reduction of Antioxidant}

Free radicals have an unpaired electron. Antioxidant vitamins $C$ and $E$ donate an electron to a free radical, thereby scavenging it. These antioxidant vitamins inhibit lipid peroxidation and nitration of tyrosine residues of proteins [224-227]. An epidemiological study showed that high intakes of vitamins $\mathrm{C}$ and $\mathrm{E}$ exhibited inverse associations with gastric cancer in $\mathrm{H}$. pylori-infected subjects compared with non-infected individuals [228]. $\gamma$-Tocopherol, a major form of vitamin E, when present at $0.1 \%$ in the 
diet decreased the number of adenomatous polyps by $85 \%$ in the AOM/DSS colon cancer model [179]. Thus, the preventive effect of antioxidants on inflammation-related carcinogenesis has been observed both in human studies and in animal experiments.

\subsection{Activation of NF- $\kappa B$}

NF- $\mathrm{kB}$ (a heterodimer of p50/NF- $\mathrm{kB1}$ and p65/RelA) is found in the cytoplasm where it is bound to IKBs that prevent its activation in unstimulated cells. IKB phosphorylation causes its ubiquitin-proteasomal degradation, leading to the release of NF- $\mathrm{kB}$, which then enters the nucleus and functions as a transcription factor of inflammation-related genes [229].

NF- $\mathrm{KB}$ has been found to be constitutively activated in inflammatory diseases, such as IBD and COPD [230,231]. Its activation is induced by pro-inflammatory cytokines (tumor necrosis factor (TNF)- $\alpha$, IL-1 $\beta$, IL-6 and IL-8), ROS, bacterial infection and ultraviolet irradiation [229,232]. NF- $\mathrm{kB}$ promotes the transcription of pro-inflammatory cytokines, leukocyte chemoattractant proteins (chemokine (C-X-C motif) ligand (CXCL)12, CCL2 and CCL3), COX-2 and endothelial adhesion molecules (E-selectin, vascular cell adhesion molecule 1 and intercellular adhesion molecule 1), leading to enhancement of inflammatory cell infiltration and inflammatory reactions $[232,233]$. NF- $\mathrm{kB}$ activation also increases the expression of ROS-producing enzymes (gp91 ${ }^{\text {phox }}$, xanthine oxidase) or inducible NO synthase (Figure 3), resulting in the promotion of cell proliferation, the acquisition of apoptosis resistance and induction of genetic instability [214,234,235].

A recent report showed that NF- $\mathrm{KB}$ promoted TNF- $\alpha$ secretion, which, in turn, activated more NF- $k B$, in acute myeloid leukemia [236]. This NF- $k B / T N F-\alpha$ positive feedback loop also exists in inflammation associated with Barrett's carcinogenesis [237], indicating that it is a common mechanism in both epithelium and non-epithelium. Inflammation-related cancer development may be suppressed by any one of the inhibitions of NF- $\kappa \mathrm{B}$ activation, downregulation of pro-inflammatory cytokines or upregulation of an anti-inflammatory cytokine (IL-10) due to breakdown of the NF- $\mathrm{kB} / \mathrm{TNF}-\alpha$ positive feedback loop.

\subsection{Upregulation of Pro-Inflammatory Cytokines}

Pro-inflammatory cytokines (e.g., IL-1 $\beta$, IL-6 and TNF- $\alpha$ ) are produced by macrophages, B and T lymphocytes, endothelial cells and fibroblasts. These cytokines exert paracrine and autocrine effects via binding to their transmembrane receptors [238-240]. These cytokines are involved in the promotion of cell proliferation, induction of angiogenesis, autophagy and inhibition of apoptosis [238]. In the DMBA/TPA skin tumor model, $100 \%$ of wild-type mice had tumors ( 7.3 tumors per mouse). In contrast, only $38 \%$ of TNF- $\alpha$-null mice developed tumors ( 0.9 tumors per mouse) because keratinocyte hyperproliferation and inflammation were diminished by deletion of TNF- $\alpha$ [241].

TNF- $\alpha$ and interferon- $\gamma$ induce autophagy, a cellular degradation process involving the amino acid recycling for cellular survival and proliferation [160,242]. Melatonin prevents the development of adenocarcinoma by suppressing of autophagy in DMH/DSS colon cancer model [160].

The inflammasome is a multi-protein complex functioning as a platform for the activation of caspase-1, which then lead to the maturation of IL-1 $\beta$ and IL-18 $[243,244]$. The activation of the inflammasome in immune cells (dendritic cells and macrophages) increases the recruitment of suppressive immune cells, such as myeloid-derived suppressor cells and regulatory $\mathrm{T}$ cells and facilitates angiogenesis through the release of fibroblast growth factor-2 and vascular endothelial growth factor [245].

Epidermal growth factor (EGF) is secreted by platelets and macrophages [246], and its expression is increased in inflammatory diseases and at wound sites $[247,248]$. To examine the effect of EGF on the tumor progression of weakly-tumorigenic and nonmetastatic rat mammary adenocarcinoma (ER-1) cells, the cells were exposed to EGF (100 ng/mL) for a short (24 h) or a long (one month) period in vitro [249]. Each EGF treatment period converted ER-1 cells into tumorigenic and metastatic cells. Their malignant features were reversible during the short exposure to EGF, but the acquired malignant 
phenotypes were fixed by long exposure. The acquisition of malignant phenotypes was prevented by the addition of an antioxidant, $N$-acetylcysteine or selenium [182,249]. It is therefore assumed that EGF that is present in an inflammatory environment stimulates ROS production, resulting in oxidative DNA damage and malignant conversion.

\subsection{Downregulation of Anti-Inflammatory Cytokines}

Anti-inflammatory cytokines such as IL-10 are produced by CD8 ${ }^{+} \mathrm{T}$ cells [250]. IL-10 inhibits NF- $\mathrm{BB}$ signaling at two levels: (i) through blocking of the activity of I $\mathrm{KB}$ kinases and (ii) through inhibition of NF-KB DNA binding [251]. All IL-10-deficient mice spontaneously developed colitis at the age of nine weeks. In 10 to 31-week-old mice, the incidence of colorectal adenocarcinomas reached $65 \%$ [252]. IL-10 has anti-inflammatory and then anti-tumorigenic properties, since it suppress levels of IL-6 and TNF- $\alpha$ [239].

\subsection{Elevation of Chemokines}

Chemokines recruit leukocytes into inflammatory sites. A high serum level of CXCL13, a B-cell chemoattractant, was associated with poor prognosis, bone marrow invasion and the presence of Epstein-Barr virus DNA in non-Hodgkin lymphoma patients [253]. In addition to CXCL13, the expression level of CCL2, a monocyte chemoattractant, was 30- to 50-times higher in the colonic mucosa from patients with ulcerative colitis and Crohn's disease than in that from controls [254]. CCL2 overexpression was also observed in the AOM/DSS colitis-associated carcinoma model [142]. The enhanced intracolonic macrophage infiltration and tumor development in this model were suppressed by using mice deficient in the CCL2-specific receptor, CCR2 [142]. Inhibition of chemokines decreases inflammatory cell infiltration and eventually attenuates carcinogenesis.

\subsection{Induction of Cyclooxygenase-2}

Prostaglandin E (PGE)2 is synthesized in multiple-steps: first, arachidonic acid is released from membrane-bound phospholipids by phospholipase A2; next, arachidonic acid conversion to prostaglandin H2 is mediated by COX; finally, PGE2 is produced by PGE synthase $[255,256]$. PGE2 causes increased cell proliferation, inhibition of apoptosis, stimulation of angiogenesis and immunosuppression in various cancers (Figure 3) [257]. In 1897, Hoffmann synthesized aspirin, a nonsteroidal anti-inflammatory drug (NSAID). Vane was the first to show that the active mechanism of aspirin was that of an inhibitor of COX [258]. The IARC evaluates NSAIDs, such as aspirin and sulindac, as cancer chemopreventive agents [259]. A clinical trial in the United Kingdom indicated that the use of aspirin for about five years was effective in the prevention of colon cancer [260]. In addition to colon cancer, a chemopreventive effect of aspirin and other NSAIDs has also been reported for esophageal, gastric, lung, breast and prostate cancers [261]. COX-2 is induced by an inflammatory stimulus (infection, a foreign body, alcohol or tobacco), whereas COX-1 is constitutively expressed in gastrointestinal epithelium, renal tubules and platelets [229,239,262]. The NSAIDs aspirin, diclofenac, ibuprofen, indomethacin, naproxen and piroxicam are nonselective inhibitors of COX isozymes, and therefore, they increase the risk of gastrointestinal events, including bleeding and ulcer [263,264]. Shortly after the first of those reports, selective COX-2 inhibitors (celecoxib, etodolac, meloxicam, rofecoxib) were developed in order to reduce adverse effects [263]. A case-control study suggests that NSAIDs including celecoxib and rofecoxib might reduce the risk of patients with Barrett's esophagus developing esophageal adenocarcinoma [265].

Selective and nonselective COX-2 inhibitors (MF-Tricyclic and sulindac, respectively) lower PGE2 levels and inhibit esophagitis and the development of adenocarcinoma in a rat model of Barrett's esophagus [211]. This cancer preventive effect was also shown in an H. pylori-infected gastric cancer model, the AOM/DSS-induced colon cancer model and a pancreatic cancer model using caerulein and K-ras mutated mice [192,210,266]. Besides NSAIDs, fermented brown rice, rice bran with Aspergillus oryzae [184] and methanol extracts from the fruit of A. communis and the leaf of 
A. communis [147] also prevent inflammation-related carcinogenesis of the colon or skin by decreasing COX-2 expression (Table 3).

\section{Candidate Chemopreventive Agents against Inflammation-Related Carcinogenesis}

Table 3 presents a summary of 79 candidate chemopreventive agents reported in 70 primary journal articles using the above-described animal models of inflammation-related carcinogenesis. The information sources for this review include PubMed (from 1996 to 2017, Available online: https://www.ncbi.nlm.nih.gov/pubmed).

These 79 agents are classified into five groups: 34 natural compounds; 16 food products; 14 low-molecular-weight compounds; 5 COX inhibitors; and 10 others. The first four groups account for $87 \%$ of the total number of isolated agents. The mechanisms of action of these groups are listed in Figure 4 and are classified into the ten above-described mechanisms involved in inflammation-related carcinogenesis. Natural compounds followed by food products have the highest number of mechanisms of action. In contrast, low-molecular-weight compounds and COX inhibitors have a much lower number of mechanisms of action. These findings indicate that natural compounds and food products prevent inflammation-related carcinogenesis more effectively than low-molecular-weight compounds and specific molecular-targeted inhibitors. Of note, food products are low-cost because they are not perceived as "medicine", and they are safe for long-term administration $[267,268]$. Cancer cases/deaths due to infection (inflammation) are expected to increase rapidly in low-income and middle-income countries within the next few decades [269]. Therefore, food products with anticarcinogenic/antiphlogistic effects may be ideal for cancer prevention in those countries.

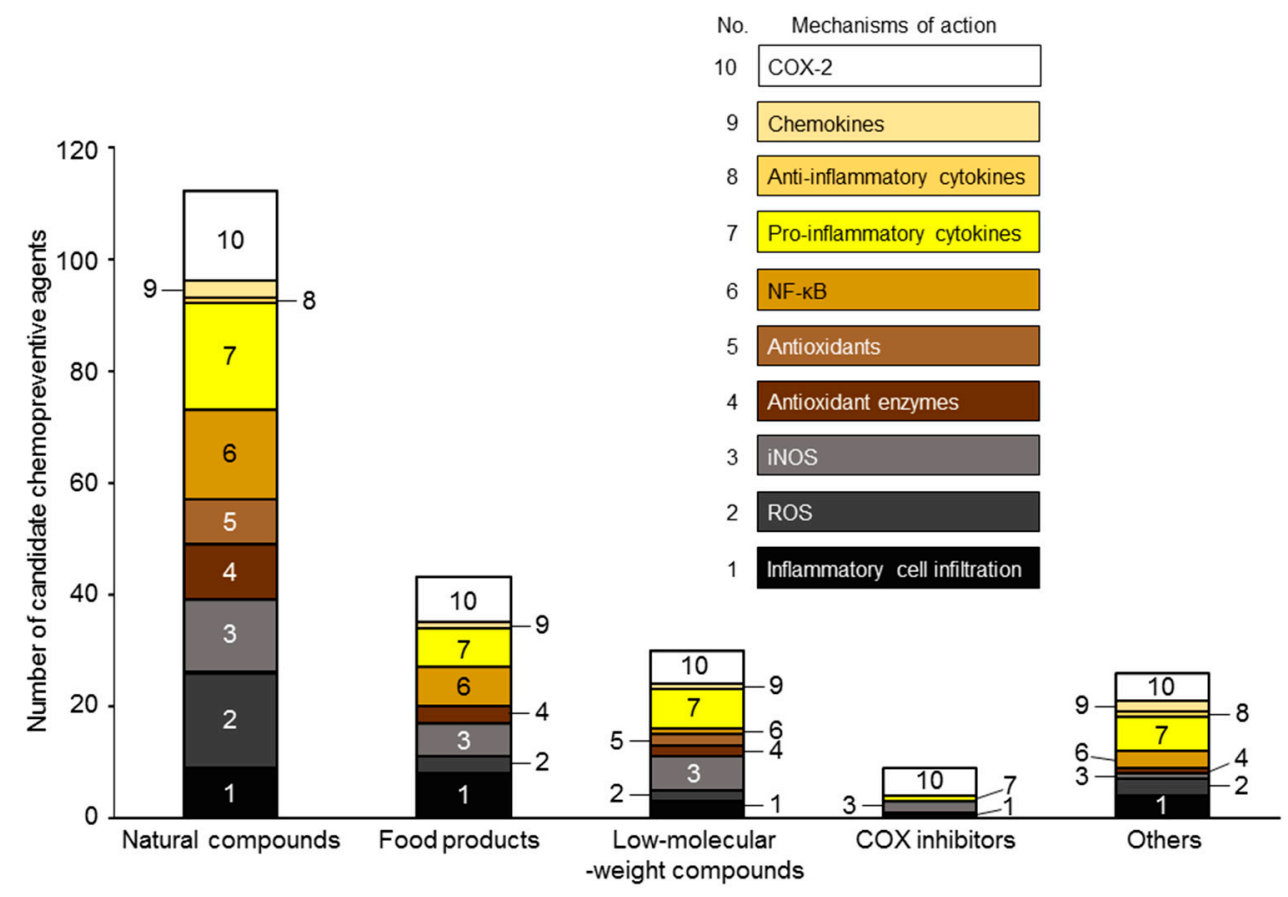

Figure 4. Natural compounds and food products have multiple chemopreventive mechanisms of action against inflammation-related carcinogenesis. The numbers of mechanisms of action of natural compounds, food products, low-molecular weight compounds, COX inhibitors and others against inflammation-related cancer development were calculated based on Table 3.

\section{Future Prospects}

Chronic inflammation is central and common to the pathogenesis of not only carcinogenesis, but also cardiovascular disorders (arteriosclerosis, polyarteritis nodosa, aortitis syndrome and myocarditis), 
autoimmune diseases (systemic lupus erythematosus, rheumatoid arthritis, Crohn's disease, type 1 diabetes, Hashimoto's thyroiditis, Graves' disease and sarcopenia), metabolic disorders (metabolic syndrome, type 2 diabetes and obesity) and neurological diseases (Alzheimer's dementia, Parkinson's disease and depression) [270-283]. Centenarians who are older than 100 years have higher levels of C-reactive protein, a sensitive indicator of inflammation, than younger people, indicating that chronic inflammation is also associated with healthy life expectancy [284]. The natural compounds and food products with preventive effects against inflammation-related cancers that are summarized in this review are expected to inhibit the above-listed inflammatory diseases because these agents have multiple inhibitory mechanisms of action.

Figure 1 shows that inflammation-related cancers develop in most organs/tissues. On the other hand, some inflammatory diseases do not increase cancer risk [285]; there has been no report showing that psoriasis or rheumatoid arthritis induces inflammation-related carcinogenesis. We assume two possible hypotheses for the difference in carcinogenic property between inflammatory diseases: (i) particular organs/tissues have resistance to carcinogenesis; (ii) the susceptibility of organs/tissues to carcinogenesis depends on the quality or the degree of the inflammatory reaction. Elucidation of these issues will lead to further understanding of the mechanism of inflammation-related carcinogenesis.

Acknowledgments: This work was supported in part by a Grant-in-Aid to Futoshi Okada from the Japanese Ministry of Education, Culture, Sports, Science and Technology; the Environmental Research and Technology Development Fund (5-1453) of the Japanese Ministry of the Environment; the Research Grant of the Princess Takamatsu Cancer Research Fund. This work was also supported in part by a Grant-in-Aid to Mitsuhiko Osaki from the Takeda Science Foundation; Yusuke Kanda was supported by the Japan Society for the Promotion of Science (Research Fellowship for Young Scientists).

Conflicts of Interest: The authors declare no conflict of interest.

\section{Abbreviations}

$\begin{array}{ll}\text { AD } & \text { Asian dust } \\ \text { AOM } & \text { Azoxymethane } \\ \text { Apc } & \text { Adenomatous polyposis coli } \\ \text { ATL } & \text { Adult T-cell leukemia } \\ \text { CCL } & \text { C-C motif chemokine ligand } \\ \text { CCl } & \text { Carbon tetra chloride } \\ \text { COPD } & \text { Chronic obstructive pulmonary disease } \\ \text { COX } & \text { Cyclooxygenase } \\ \text { CXCL } & \text { Chemokine (C-X-C motif) ligand } \\ \text { DBM } & \text { Dibenzoylmethane } \\ \text { DEN } & \text { Diethylnitrosamine } \\ \text { DLBC } & \text { Diffuse large B-cell } \\ \text { DMBA } & 7,12-\text { Dimethylbenz[a]-anthracene } \\ \text { DMH } & \text { Dimethylhydrazine } \\ \text { DSS } & \text { Dextran sulfate sodium } \\ \text { EAPP } & \text { Ethanol extracts from the aerial parts of A. princeps Pampanini cv. Sajabal } \\ \text { EBV } & \text { Epstein-Barr virus } \\ \text { EGF } & \text { Epidermal growth factor } \\ \text { EVOO } & \text { Extra virgin olive oil } \\ \text { FAP } & \text { Familial adenomatous polyposis } \\ \text { FBE } & \text { Fruiting body extract } \\ \text { FBRA } & \text { Fermented brown rice and rice bran with Aspergillus oryzae } \\ \text { GOFA / } \beta-C D & 3-\left(4^{\prime} \text {-Geranyloxy-3'-methoxyphenyl)-2-trans propenoic acid/ } \beta \text {-cyclodextrin }\right. \\ \text { GOFA-L-NAME } & 4^{\prime} \text {-Geranyloxyferulic acid-N(omega)-nitro-L-arginine methyl ester } \\ & \end{array}$




\begin{tabular}{|c|c|}
\hline H. felis & Helicobacter felis \\
\hline H. pylori & Helicobacter pylori \\
\hline HBV & Hepatitis B virus \\
\hline $\mathrm{HCC}$ & Hepatocellular carcinoma \\
\hline $\mathrm{HCV}$ & Hepatitis $C$ virus \\
\hline HDV & Hepatitis D virus \\
\hline HERV-K & Human endogenous retrovirus type $\mathrm{K}$ \\
\hline HIV & Human immunodeficiency virus \\
\hline HPV & Human papillomavirus \\
\hline HTLV-1 & Human T-cell lymphotropic virus type 1 \\
\hline IARC & International Agency for Research on Cancer \\
\hline IBD & Inflammatory bowel disease \\
\hline IL & Interleukin \\
\hline iNOS & Inducible nitric oxide synthase \\
\hline $\mathrm{JCV}$ & JC virus \\
\hline KSHV & Kaposi sarcoma herpes virus \\
\hline MALT & Mucosa-associated lymphoid tissue \\
\hline $\mathrm{MCV}$ & Molluscum contagiosum virus \\
\hline MDA & Malondialdehydes \\
\hline ME & Mycelia extract \\
\hline MEFA & Methanol extracts of the fruit of $A$. communis \\
\hline MELA & Methanol extract of the leaf of $A$. communis \\
\hline $\mathrm{MiR}$ & MicroRNA \\
\hline MNNG & $N$-Methyl- $N^{\prime}$-nitro- $N$-nitrosoguanidine \\
\hline Mn-SOD & Manganese superoxide dismutase \\
\hline NDMA & $\mathrm{N}$-Nitrosodimethylamine \\
\hline $\mathrm{NO}$ & Nitric oxide \\
\hline NSAID & Nonsteroidal anti-inflammatory drug \\
\hline O. viverrini & Opisthorchis viverrini \\
\hline PAG & Processed Aloe vera gel \\
\hline PBM & Pancreaticobiliary maljunction \\
\hline PDAC & Pancreatic ductal adenocarcinomas \\
\hline PEITC & Phenethyl isothiocyanate \\
\hline PGE & Prostaglandin E \\
\hline $\mathrm{PhIP}$ & 2-Amino-1-methyl-6-phenylimidazo[4,5-b] pyridine \\
\hline PSK & Polysaccharide K \\
\hline ROS & Reactive oxygen species \\
\hline SCC & Squamous cell carcinoma \\
\hline TNF & Tumor necrosis factor \\
\hline TPA & 12-O-Tetradecanoylphorbol-13-acetate \\
\hline UDCA & Ursodeoxycholic acid \\
\hline UV & Ultraviolet \\
\hline$\gamma-\operatorname{TmT}$ & $\gamma$-Tocopherol-rich mixture of tocopherols \\
\hline 4-HNE & 4-Hydroxynonenal \\
\hline $5-\mathrm{OH}-\mathrm{H} x \mathrm{MF}$ & 5-Hydroxy-3,6,7,8,3', $4^{\prime}$-hexamethoxyflavone \\
\hline 13-HOA & $( \pm)-13$-Hydroxy-10-oxo-trans-11-octadecenoic acid \\
\hline
\end{tabular}

\section{References}

1. Balkwill, F.; Mantovani, A. Inflammation and cancer: Back to Virchow? Lancet 2001, 357, 539-545. [CrossRef]

2. Parkin, D.M. The global health burden of infection-associated cancers in the year 2002. Int. J. Cancer 2006, 118, 3030-3044. [CrossRef] [PubMed]

3. Belpomme, D.; Irigaray, P.; Hardell, L.; Clapp, R.; Montagnier, L.; Epstein, S.; Sasco, A.J. The multitude and diversity of environmental carcinogens. Environ. Res. 2007, 105, 414-429. [CrossRef] [PubMed] 
4. Lu, L.; Chan, R.L.; Luo, X.M.; Wu, W.K.; Shin, V.Y.; Cho, C.H. Animal models of gastrointestinal inflammation and cancer. Life Sci. 2014, 108, 1-6. [CrossRef] [PubMed]

5. Maeda, S.; Omata, M. Inflammation and cancer: Role of nuclear factor-кB activation. Cancer Sci. 2008, 99, 836-842. [CrossRef] [PubMed]

6. Mantovani, A.; Allavena, P.; Sica, A.; Balkwill, F. Cancer-related inflammation. Nature 2008, 454, 436-444. [CrossRef] [PubMed]

7. Ostry, V.; Malir, F.; Toman, J.; Grosse, Y. Mycotoxins as human carcinogens-the IARC Monographs classification. Mycotoxin Res. 2017, 33, 65-73. [CrossRef] [PubMed]

8. Cogliano, V.J.; Baan, R.; Straif, K.; Grosse, Y.; Lauby-Secretan, B.; El Ghissassi, F.; Bouvard, V.; Benbrahim-Tallaa, L.; Guha, N.; Freeman, C.; et al. Preventable exposures associated with human cancers. J. Natl. Cancer Inst. 2011, 103, 1827-1839. [CrossRef] [PubMed]

9. Elinav, E.; Nowarski, R.; Thaiss, C.A.; Hu, B.; Jin, C.; Flavell, R.A. Inflammation-induced cancer: Crosstalk between tumours, immune cells and microorganisms. Nat. Rev. Cancer 2013, 13, 759-771. [CrossRef] [PubMed]

10. Ohshima, H.; Miyoshi, N.; Tomono, S. Infection, Inflammation, and Cancer: Overview. In Cancer and Inflammation Mechanisms; John Wiley \& Sons, Inc.: Hoboken, NJ, USA, 2014; pp. 1-7.

11. Wen, B.W.; Tsai, C.S.; Lin, C.L.; Chang, Y.J.; Lee, C.F.; Hsu, C.H.; Kao, C.H. Cancer risk among gingivitis and periodontitis patients: A nationwide cohort study. QJM 2014, 107, 283-290. [CrossRef] [PubMed]

12. IARC Working Group on the Evaluation of Carcinogenic Risks to Humans. Biological agents. Volume 100 B. A review of human carcinogens. IARC Monogr. Eval. Carcinog. Risks Hum. 2012, 100, 1-441.

13. Siirala, U. Tongue cancer. Acta Otolaryngol. 1973, 75, 309. [CrossRef] [PubMed]

14. Lee, J.H.; Kim, Y.; Choi, J.W.; Kim, Y.S. The association between papillary thyroid carcinoma and histologically proven Hashimoto's thyroiditis: A meta-analysis. Eur. J. Endocrinol. 2013, 168, 343-349. [CrossRef] [PubMed]

15. Muto, M.; Hitomi, Y.; Ohtsu, A.; Shimada, H.; Kashiwase, Y.; Sasaki, H.; Yoshida, S.; Esumi, H. Acetaldehyde production by non-pathogenic Neisseria in human oral microflora: Implications for carcinogenesis in upper aerodigestive tract. Int. J. Cancer 2000, 88, 342-350. [CrossRef]

16. Loomis, D.; Grosse, Y.; Lauby-Secretan, B.; El Ghissassi, F.; Bouvard, V.; Benbrahim-Tallaa, L.; Guha, N.; Baan, R.; Mattock, H.; Straif, K.; et al. The carcinogenicity of outdoor air pollution. Lancet Oncol. 2013, 14, 1262-1263. [CrossRef]

17. Santillan, A.A.; Camargo, C.A., Jr.; Colditz, G.A. A meta-analysis of asthma and risk of lung cancer (United States). Cancer Causes Control 2003, 14, 327-334. [CrossRef] [PubMed]

18. Houghton, A.M. Mechanistic links between COPD and lung cancer. Nat. Rev. Cancer 2013, 13, $233-245$. [CrossRef] [PubMed]

19. Matsushita, H.; Tanaka, S.; Saiki, Y.; Hara, M.; Nakata, K.; Tanimura, S.; Banba, J. Lung cancer associated with usual interstitial pneumonia. Pathol. Int. 1995, 45, 925-932. [CrossRef] [PubMed]

20. Yamaguchi, M.; Odaka, M.; Hosoda, Y.; Iwai, K.; Tachibana, T. Excess death of lung cancer among sarcoidosis patients. Sarcoidosis 1991, 8, 51-55. [PubMed]

21. Wu, C.Y.; Hu, H.Y.; Pu, C.Y.; Huang, N.; Shen, H.C.; Li, C.P.; Chou, Y.J. Pulmonary tuberculosis increases the risk of lung cancer: A population-based cohort study. Cancer 2011, 117, 618-624. [CrossRef] [PubMed]

22. Zhan, P.; Suo, L.J.; Qian, Q.; Shen, X.K.; Qiu, L.X.; Yu, L.K.; Song, Y. Chlamydia pneumoniae infection and lung cancer risk: A meta-analysis. Eur. J. Cancer 2011, 47, 742-747. [CrossRef] [PubMed]

23. Ragin, C.; Obikoya-Malomo, M.; Kim, S.; Chen, Z.; Flores-Obando, R.; Gibbs, D.; Koriyama, C.; Aguayo, F.; Koshiol, J.; Caporaso, N.E.; et al. HPV-associated lung cancers: An international pooled analysis. Carcinogenesis 2014, 35, 1267-1275. [CrossRef] [PubMed]

24. Kirk, G.D.; Merlo, C.; O’Driscoll, P.; Mehta, S.H.; Galai, N.; Vlahov, D.; Samet, J.; Engels, E.A. HIV infection is associated with an increased risk for lung cancer, independent of smoking. Clin. Infect. Dis. 2007, 45, 103-110. [CrossRef] [PubMed]

25. Steenland, K.; Stayner, L. Silica, asbestos, man-made mineral fibers, and cancer. Cancer Causes Control 1997, 8, 491-503. [CrossRef] [PubMed]

26. Salmons, B.; Lawson, J.S.; Gunzburg, W.H. Recent developments linking retroviruses to human breast cancer: Infectious agent, enemy within or both? J. Gen. Virol. 2014, 95, 2589-2593. [CrossRef] [PubMed]

27. Grabowski, J.; Wedemeyer, H. Hepatitis delta: Immunopathogenesis and clinical challenges. Dig. Dis. 2010, 28, 133-138. [CrossRef] [PubMed] 
28. Abdel-Hamid, N.M. Recent insights on risk factors of hepatocellular carcinoma. World J. Hepatol. 2009, 1, 3-7. [CrossRef] [PubMed]

29. Singh, S.; Talwalkar, J.A. Primary sclerosing cholangitis: Diagnosis, prognosis, and management. Clin. Gastroenterol. Hepatol. 2013, 11, 898-907. [CrossRef] [PubMed]

30. Kamisawa, T.; Kuruma, S.; Chiba, K.; Tabata, T.; Koizumi, S.; Kikuyama, M. Biliary carcinogenesis in pancreaticobiliary maljunction. J. Gastroenterol. 2017, 52, 158-163. [CrossRef] [PubMed]

31. Scanu, T.; Spaapen, R.M.; Bakker, J.M.; Pratap, C.B.; Wu, L.E.; Hofland, I.; Broeks, A.; Shukla, V.K.; Kumar, M.; Janssen, H.; et al. Salmonella manipulation of host signaling pathways provokes cellular transformation associated with gallbladder carcinoma. Cell Host Microbe 2015, 17, 763-774. [CrossRef] [PubMed]

32. Weiss, F.U. Pancreatic cancer risk in hereditary pancreatitis. Front. Physiol. 2014, 5, 70. [CrossRef] [PubMed]

33. Zheng, W.; McLaughlin, J.K.; Gridley, G.; Bjelke, E.; Schuman, L.M.; Silverman, D.T.; Wacholder, S.; Co-Chien, H.T.; Blot, W.J.; Fraumeni, J.F., Jr. A cohort study of smoking, alcohol consumption, and dietary factors for pancreatic cancer (United States). Cancer Causes Control 1993, 4, 477-482. [CrossRef] [PubMed]

34. Hartnett, L.; Egan, L.J. Inflammation, DNA methylation and colitis-associated cancer. Carcinogenesis 2012, 33, 723-731. [CrossRef] [PubMed]

35. Collins, D.; Hogan, A.M.; Winter, D.C. Microbial and viral pathogens in colorectal cancer. Lancet Oncol. 2011, 12, 504-512. [CrossRef]

36. Tjalsma, H.; Boleij, A.; Marchesi, J.R.; Dutilh, B.E. A bacterial driver-passenger model for colorectal cancer: Beyond the usual suspects. Nat. Rev. Microbiol. 2012, 10, 575-582. [CrossRef] [PubMed]

37. Boleij, A.; van Gelder, M.M.; Swinkels, D.W.; Tjalsma, H. Clinical importance of streptococcus gallolyticus infection among colorectal cancer patients: Systematic review and meta-analysis. Clin. Infect. Dis. 2011, 53, 870-878. [CrossRef] [PubMed]

38. Thomas, J.E.; Bassett, M.T.; Sigola, L.B.; Taylor, P. Relationship between bladder cancer incidence, Schistosoma haematobium infection, and geographical region in Zimbabwe. Trans. R. Soc. Trop. Med. Hyg. 1990, 84, 551-553. [CrossRef]

39. West, D.A.; Cummings, J.M.; Longo, W.E.; Virgo, K.S.; Johnson, F.E.; Parra, R.O. Role of chronic catheterization in the development of bladder cancer in patients with spinal cord injury. Urology 1999, 53, 292-297. [CrossRef]

40. Ky, A.; Sohn, N.; Weinstein, M.A.; Korelitz, B.I. Carcinoma arising in anorectal fistulas of Crohn's disease. Dis. Colon Rectum. 1998, 41, 992-996. [CrossRef] [PubMed]

41. Akre, O.; Lipworth, L.; Tretli, S.; Linde, A.; Engstrand, L.; Adami, H.O.; Melbye, M.; Andersen, A.; Ekbom, A. Epstein-Barr virus and cytomegalovirus in relation to testicular-cancer risk: A nested case-control study. Int. J. Cancer 1999, 82, 1-5. [CrossRef]

42. De Marzo, A.M.; Platz, E.A.; Sutcliffe, S.; Xu, J.; Gronberg, H.; Drake, C.G.; Nakai, Y.; Isaacs, W.B.; Nelson, W.G. Inflammation in prostate carcinogenesis. Nat. Rev. Cancer 2007, 7, 256-269. [CrossRef] [PubMed]

43. Dennis, L.K.; Dawson, D.V. Meta-analysis of measures of sexual activity and prostate cancer. Epidemiology 2002, 13, 72-79. [CrossRef] [PubMed]

44. Stark, J.R.; Judson, G.; Alderete, J.F.; Mundodi, V.; Kucknoor, A.S.; Giovannucci, E.L.; Platz, E.A.; Sutcliffe, S.; Fall, K.; Kurth, T.; et al. Prospective study of Trichomonas vaginalis infection and prostate cancer incidence and mortality: Physicians' health study. J. Natl. Cancer Inst. 2009, 101, 1406-1411. [CrossRef] [PubMed]

45. Kralickova, M.; Vetvicka, V. Endometriosis and ovarian cancer. World J. Clin. Oncol. 2014, 5, 800-805. [CrossRef] [PubMed]

46. Bleeker, M.C.; Visser, P.J.; Overbeek, L.I.; van Beurden, M.; Berkhof, J. Lichen sclerosus: Incidence and risk of vulvar squamous cell carcinoma. Cancer Epidemiol. Biomark. Prev. 2016, 25, 1224-1230. [CrossRef] [PubMed]

47. Hejna, W.F. Squamous-cell carcinoma developing in the chronic draining sinuses of osteomyelitis. Cancer 1965, 18, 128-132. [CrossRef]

48. Arron, S.T.; Jennings, L.; Nindl, I.; Rosl, F.; Bouwes Bavinck, J.N.; Seckin, D.; Trakatelli, M.; Murphy, G.M. Viral Working Group of the International Transplant Skin Cancer Collaborative (ITSCC); Care in Organ Transplant Patients, Europe (SCOPE). Viral oncogenesis and its role in nonmelanoma skin cancer. Br. J. Dermatol. 2011, 164, 1201-1213. [CrossRef] [PubMed]

49. Reiss, K.; Khalili, K. Viruses and cancer: Lessons from the human polyomavirus, JCV. Oncogene 2003, 22, 6517-6523. [CrossRef] [PubMed] 
50. Dehio, C. Bartonella-host-cell interactions and vascular tumour formation. Nat. Rev. Microbiol. 2005, 3, 621-631. [CrossRef] [PubMed]

51. Grulich, A.E.; van Leeuwen, M.T.; Falster, M.O.; Vajdic, C.M. Incidence of cancers in people with HIV / AIDS compared with immunosuppressed transplant recipients: A meta-analysis. Lancet 2007, 370, 59-67. [CrossRef]

52. Jeong, S.H. HBV infection as a risk factor for non-Hodgkin lymphoma. Lancet Oncol. 2010, 11, 806. [CrossRef]

53. Colebunders, R.; de Vuyst, H.; Verstraeten, T.; Schroyens, W.; van Marck, E. A non-Hodgkin's lymphoma in a patient with HIV-2 infection. Genitourin. Med. 1995, 71, 129. [CrossRef] [PubMed]

54. Green, P.H.; Fleischauer, A.T.; Bhagat, G.; Goyal, R.; Jabri, B.; Neugut, A.I. Risk of malignancy in patients with celiac disease. Am. J. Med. 2003, 115, 191-195. [CrossRef]

55. Galun, E.; Ilan, Y.; Livni, N.; Ketzinel, M.; Nahor, O.; Pizov, G.; Nagler, A.; Eid, A.; Rivkind, A.; Laster, M.; et al. Hepatitis B virus infection associated with hematopoietic tumors. Am. J. Pathol. 1994, 145, 1001-1007. [PubMed]

56. Coffin, J.M. The discovery of HTLV-1, the first pathogenic human retrovirus. Proc. Natl. Acad. Sci. USA 2015, 112, 15525-15529. [CrossRef] [PubMed]

57. Ferreri, A.J.; Guidoboni, M.; Ponzoni, M.; de Conciliis, C.; Dell'Oro, S.; Fleischhauer, K.; Caggiari, L.; Lettini, A.A.; Dal Cin, E.; Ieri, R.; et al. Evidence for an association between Chlamydia psittaci and ocular adnexal lymphomas. J. Natl. Cancer Inst. 2004, 96, 586-594. [CrossRef] [PubMed]

58. Aozasa, K. Hashimoto's thyroiditis as a risk factor of thyroid lymphoma. Acta Pathol. Jpn. 1990, 40, 459-468. [CrossRef] [PubMed]

59. Molinie, V.; Pouchot, J.; Navratil, E.; Aubert, F.; Vinceneux, P.; Barge, J. Primary Epstein-Barr virus-related non-Hodgkin's lymphoma of the pleural cavity following long-standing tuberculous empyema. Arch. Pathol. Lab. Med. 1996, 120, 288-291. [PubMed]

60. Aozasa, K.; Takakuwa, T.; Nakatsuka, S. Pyothorax-associated lymphoma: A lymphoma developing in chronic inflammation. Adv. Anat. Pathol. 2005, 12, 324-331. [CrossRef] [PubMed]

61. Lecuit, M.; Abachin, E.; Martin, A.; Poyart, C.; Pochart, P.; Suarez, F.; Bengoufa, D.; Feuillard, J.; Lavergne, A.; Gordon, J.I.; et al. Immunoproliferative small intestinal disease associated with Campylobacter jejuni. N. Engl. J. Med. 2004, 350, 239-248. [CrossRef] [PubMed]

62. Goodlad, J.R.; Davidson, M.M.; Hollowood, K.; Ling, C.; MacKenzie, C.; Christie, I.; Batstone, P.J.; Ho-Yen, D.O. Primary cutaneous B-cell lymphoma and Borrelia burgdorferi infection in patients from the Highlands of Scotland. Am. J. Surg. Pathol. 2000, 24, 1279-1285. [CrossRef] [PubMed]

63. Yasunaga, J.; Matsuoka, M. Molecular mechanisms of HTLV-1 infection and pathogenesis. Int. J. Hematol. 2011, 94, 435-442. [CrossRef] [PubMed]

64. Piccaluga, P.P.; Gazzola, A.; Agostinelli, C.; Bacci, F.; Sabattini, E.; Pileri, S.A. Pathobiology of Epstein-Barr virus-driven peripheral T-cell lymphomas. Semin. Diagn. Pathol. 2011, 28, 234-244. [CrossRef] [PubMed]

65. Rochford, R.; Moormann, A.M. Burkitt's Lymphoma. Curr. Top. Microbiol. Immunol. 2015, 390, $267-285$. [PubMed]

66. Grywalska, E.; Rolinski, J. Epstein-Barr virus-associated lymphomas. Semin. Oncol. 2015, 42, $291-303$. [CrossRef] [PubMed]

67. Wen, K.W.; Damania, B. Kaposi sarcoma-associated herpesvirus (KSHV): Molecular biology and oncogenesis. Cancer Lett. 2010, 289, 140-150. [CrossRef] [PubMed]

68. Samaras, V.; Rafailidis, P.I.; Mourtzoukou, E.G.; Peppas, G.; Falagas, M.E. Chronic bacterial and parasitic infections and cancer: A review. J. Infect. Dev. Ctries 2010, 4, 267-281. [PubMed]

69. Mesri, E.A.; Feitelson, M.A.; Munger, K. Human viral oncogenesis: A cancer hallmarks analysis. Cell Host Microbe 2014, 15, 266-282. [CrossRef] [PubMed]

70. Wang, F.; Meng, W.; Wang, B.; Qiao, L. Helicobacter pylori-induced gastric inflammation and gastric cancer. Cancer Lett. 2014, 345, 196-202. [CrossRef] [PubMed]

71. Okada, F. Beyond foreign-body-induced carcinogenesis: Impact of reactive oxygen species derived from inflammatory cells in tumorigenic conversion and tumor progression. Int. J. Cancer 2007, 121, 2364-2372. [CrossRef] [PubMed]

72. Nagai, H.; Toyokuni, S. Biopersistent fiber-induced inflammation and carcinogenesis: Lessons learned from asbestos toward safety of fibrous nanomaterials. Arch. Biochem. Biophys. 2010, 502, 1-7. [CrossRef] [PubMed] 
73. Chew, S.H.; Toyokuni, S. Malignant mesothelioma as an oxidative stress-induced cancer: An update. Free Radic. Biol. Med. 2015, 86, 166-178. [CrossRef] [PubMed]

74. Kzhyshkowska, J.; Gudima, A.; Riabov, V.; Dollinger, C.; Lavalle, P.; Vrana, N.E. Macrophage responses to implants: Prospects for personalized medicine. J. Leukoc. Biol. 2015, 98, 953-962. [CrossRef] [PubMed]

75. Nagai, H.; Toyokuni, S. Differences and similarities between carbon nanotubes and asbestos fibers during mesothelial carcinogenesis: Shedding light on fiber entry mechanism. Cancer Sci. 2012, 103, 1378-1390. [CrossRef] [PubMed]

76. Xing, Y.F.; Xu, Y.H.; Shi, M.H.; Lian, Y.X. The impact of PM2.5 on the human respiratory system. J. Thorac. Dis. 2016, 8, E69-E74. [PubMed]

77. Watanabe, M.; Noma, H.; Kurai, J.; Sano, H.; Saito, R.; Abe, S.; Kimura, Y.; Aiba, S.; Oshimura, M.; Yamasaki, A.; et al. Decreased pulmonary function in school children in Western Japan after exposures to Asian desert dusts and its association with interleukin-8. BioMed Res. Int. 2015, 2015, 583293. [CrossRef] [PubMed]

78. Watanabe, M.; Noma, H.; Kurai, J.; Sano, H.; Kitano, H.; Saito, R.; Kimura, Y.; Aiba, S.; Oshimura, M.; Shimizu, E. Variation in the effect of particulate matter on pulmonary function in schoolchildren in western japan and its relation with interleukin-8. Int. J. Environ. Res. Public Health 2015, 12, 14229-14243. [CrossRef] [PubMed]

79. Watanabe, M.; Noma, H.; Kurai, J.; Sano, H.; Ueda, Y.; Mikami, M.; Yamamoto, H.; Tokuyasu, H.; Kato, K.; Konishi, T.; et al. Differences in the effects of Asian dust on pulmonary function between adult patients with asthma and those with asthma-chronic obstructive pulmonary disease overlap syndrome. Int. J. Chronic Obstr. Pulm. Dis. 2016, 11, 183-190. [CrossRef] [PubMed]

80. Turner, M.C.; Krewski, D.; Pope, C.A., III; Chen, Y.; Gapstur, S.M.; Thun, M.J. Long-term ambient fine particulate matter air pollution and lung cancer in a large cohort of never-smokers. Am. J. Respir. Crit. Care Med. 2011, 184, 1374-1381. [CrossRef] [PubMed]

81. King, P.T. Inflammation in chronic obstructive pulmonary disease and its role in cardiovascular disease and lung cancer. Clin. Transl. Med. 2015, 4, 68. [CrossRef] [PubMed]

82. Young, R.P.; Hopkins, R.J.; Christmas, T.; Black, P.N.; Metcalf, P.; Gamble, G.D. COPD prevalence is increased in lung cancer, independent of age, sex and smoking history. Eur. Respir. J. 2009, 34, 380-386. [CrossRef] [PubMed]

83. Hong, W.K.; Sporn, M.B. Recent advances in chemoprevention of cancer. Science 1997, 278, $1073-1077$. [CrossRef] [PubMed]

84. Miwa, K.; Sahara, H.; Segawa, M.; Kinami, S.; Sato, T.; Miyazaki, I.; Hattori, T. Reflux of duodenal or gastro-duodenal contents induces esophageal carcinoma in rats. Int. J. Cancer 1996, 67, 269-274. [CrossRef]

85. Tatematsu, M.; Yamamoto, M.; Shimizu, N.; Yoshikawa, A.; Fukami, H.; Kaminishi, M.; Oohara, T.; Sugiyama, A.; Ikeno, T. Induction of glandular stomach cancers in Helicobacter pylori-sensitive Mongolian gerbils treated with $N$-methyl- $N$-nitrosourea and $N$-methyl- $N^{\prime}$-nitro- $N$-nitrosoguanidine in drinking water. Jpn. J. Cancer Res. 1998, 89, 97-104. [CrossRef] [PubMed]

86. Clapper, M.L.; Cooper, H.S.; Chang, W.C. Dextran sulfate sodium-induced colitis-associated neoplasia: A promising model for the development of chemopreventive interventions. Acta Pharmacol. Sin. 2007, 28, 1450-1459. [CrossRef] [PubMed]

87. Tanaka, T. Animal models of carcinogenesis in inflamed colorectum: Potential use in chemoprevention study. Curr. Drug Targets 2012, 13, 1689-1697. [CrossRef] [PubMed]

88. Dunsford, H.A.; Sell, S.; Chisari, F.V. Hepatocarcinogenesis due to chronic liver cell injury in hepatitis B virus transgenic mice. Cancer Res. 1990, 50, 3400-3407. [PubMed]

89. Schiffer, E.; Housset, C.; Cacheux, W.; Wendum, D.; Desbois-Mouthon, C.; Rey, C.; Clergue, F.; Poupon, R.; Barbu, V.; Rosmorduc, O. Gefitinib, an EGFR inhibitor, prevents hepatocellular carcinoma development in the rat liver with cirrhosis. Hepatology 2005, 41, 307-314. [CrossRef] [PubMed]

90. Uehara, T.; Ainslie, G.R.; Kutanzi, K.; Pogribny, I.P.; Muskhelishvili, L.; Izawa, T.; Yamate, J.; Kosyk, O.; Shymonyak, S.; Bradford, B.U.; et al. Molecular mechanisms of fibrosis-associated promotion of liver carcinogenesis. Toxicol. Sci. 2013, 132, 53-63. [CrossRef] [PubMed]

91. Thamavit, W.; Bhamarapravati, N.; Sahaphong, S.; Vajrasthira, S.; Angsubhakorn, S. Effects of dimethylnitrosamine on induction of cholangiocarcinoma in Opisthorchis viverrini-infected Syrian golden hamsters. Cancer Res. 1978, 38, 4634-4639. [PubMed] 
92. Tajima, Y.; Eto, T.; Tsunoda, T.; Tomioka, T.; Inoue, K.; Fukahori, T.; Kanematsu, T. Induction of extrahepatic biliary carcinoma by $\mathrm{N}$-nitrosobis(2-oxopropyl)amine in hamsters given cholecystoduodenostomy with dissection of the common duct. Jpn. J. Cancer Res. 1994, 85, 780-788. [CrossRef] [PubMed]

93. Guerra, C.; Schuhmacher, A.J.; Canamero, M.; Grippo, P.J.; Verdaguer, L.; Perez-Gallego, L.; Dubus, P.; Sandgren, E.P.; Barbacid, M. Chronic pancreatitis is essential for induction of pancreatic ductal adenocarcinoma by K-Ras oncogenes in adult mice. Cancer Cell 2007, 11, 291-302. [CrossRef] [PubMed]

94. Schwarz, M.; Munzel, P.A.; Braeuning, A. Non-melanoma skin cancer in mouse and man. Arch. Toxicol. 2013, 87, 783-978. [CrossRef] [PubMed]

95. Kapoor, H.; Lohani, K.R.; Lee, T.H.; Agrawal, D.K.; Mittal, S.K. Animal models of Barrett's esophagus and esophageal adenocarcinoma-Past, present, and future. Clin. Transl. Sci. 2015, 8, 841-847. [CrossRef] [PubMed]

96. Pham, T.H.; Genta, R.M.; Spechler, S.J.; Souza, R.F.; Wang, D.H. Development and characterization of a surgical mouse model of reflux esophagitis and Barrett's esophagus. J. Gastrointest. Surg. 2014, 18, 234-240. [CrossRef] [PubMed]

97. Buskens, C.J.; Hulscher, J.B.; van Gulik, T.M.; Ten Kate, F.J.; van Lanschot, J.J. Histopathologic evaluation of an animal model for Barrett's esophagus and adenocarcinoma of the distal esophagus. J. Surg. Res. 2006, 135, 337-344. [CrossRef] [PubMed]

98. Fox, J.G.; Wang, T.C.; Rogers, A.B.; Poutahidis, T.; Ge, Z.; Taylor, N.; Dangler, C.A.; Israel, D.A.; Krishna, U.; Gaus, K.; et al. Host and microbial constituents influence Helicobacter pylori-induced cancer in a murine model of hypergastrinemia. Gastroenterology 2003, 124, 1879-1890. [CrossRef]

99. Rogers, A.B.; Fox, J.G. Inflammation and Cancer. I. Rodent models of infectious gastrointestinal and liver cancer. Am. J. Physiol. Gastrointest. Liver Physiol. 2004, 286, G361-G366. [CrossRef] [PubMed]

100. Tsukamoto, T.; Toyoda, T.; Mizoshita, T.; Tatematsu, M. Helicobacter pylori infection and gastric carcinogenesis in rodent models. Semin. Immunopathol. 2013, 35, 177-190. [CrossRef] [PubMed]

101. Mohammadi, M.; Redline, R.; Nedrud, J.; Czinn, S. Role of the host in pathogenesis of Helicobacter-associated gastritis: H. felis infection of inbred and congenic mouse strains. Infect. Immun. 1996, 64, 238-245. [PubMed]

102. Nakamura, Y.; Sakagami, T.; Yamamoto, N.; Yokota, Y.; Koizuka, H.; Hori, K.; Fukuda, Y.; Tanida, N.; Kobayashi, T.; Shimoyama, T. Helicobacter pylori does not promote $N$-methyl-N-nitrosourea-induced gastric carcinogenesis in SPF C57BL/6 mice. Jpn. J. Cancer Res. 2002, 93, 111-116. [CrossRef] [PubMed]

103. Perse, M.; Cerar, A. Dextran sodium sulphate colitis mouse model: Traps and tricks. J. Biomed. Biotechnol. 2012, 2012, 718617. [CrossRef] [PubMed]

104. Melgar, S.; Karlsson, A.; Michaelsson, E. Acute colitis induced by dextran sulfate sodium progresses to chronicity in C57BL/ 6 but not in BALB/c mice: Correlation between symptoms and inflammation. Am. J. Physiol. Gastrointest. Liver Physiol. 2005, 288, 1328-1338. [CrossRef] [PubMed]

105. Cooper, H.S.; Murthy, S.N.; Shah, R.S.; Sedergran, D.J. Clinicopathologic study of dextran sulfate sodium experimental murine colitis. Lab. Investig. 1993, 69, 238-249. [PubMed]

106. Hursting, S.D.; Slaga, T.J.; Fischer, S.M.; DiGiovanni, J.; Phang, J.M. Mechanism-based cancer prevention approaches: Targets, examples, and the use of transgenic mice. J. Natl. Cancer Inst. 1999, 91, 215-225. [CrossRef] [PubMed]

107. Kettunen, H.L.; Kettunen, A.S.; Rautonen, N.E. Intestinal immune responses in wild-type and Apc ${ }^{\mathrm{min} /+}$ mouse, a model for colon cancer. Cancer Res. 2003, 63, 5136-5142. [PubMed]

108. Tanaka, T.; Kohno, H.; Suzuki, R.; Hata, K.; Sugie, S.; Niho, N.; Sakano, K.; Takahashi, M.; Wakabayashi, K. Dextran sodium sulfate strongly promotes colorectal carcinogenesis in Apc $\mathrm{Min}^{++}$mice: Inflammatory stimuli by dextran sodium sulfate results in development of multiple colonic neoplasms. Int. J. Cancer 2006, 118, 25-34. [CrossRef] [PubMed]

109. Bakiri, L.; Wagner, E.F. Mouse models for liver cancer. Mol. Oncol. 2013, 7, 206-223. [CrossRef] [PubMed]

110. Babinet, C.; Farza, H.; Morello, D.; Hadchouel, M.; Pourcel, C. Specific expression of hepatitis B surface antigen (HBsAg) in transgenic mice. Science 1985, 230, 1160-1163. [CrossRef] [PubMed]

111. McGivern, D.R.; Lemon, S.M. Virus-specific mechanisms of carcinogenesis in hepatitis C virus associated liver cancer. Oncogene 2011, 30, 1969-1983. [CrossRef] [PubMed]

112. Rajewsky, M.F.; Dauber, W.; Frankenberg, H. Liver carcinogenesis by diethylnitrosamine in the rat. Science 1966, 152, 83-85. [CrossRef] [PubMed] 
113. Thamavit, W.; Kongkanuntn, R.; Tiwawech, D.; Moore, M.A. Level of Opisthorchis infestation and carcinogen dose-dependence of cholangiocarcinoma induction in Syrian golden hamsters. Virchows Arch. B Cell Pathol. Incl. Mol. Pathol. 1987, 54, 52-58. [CrossRef] [PubMed]

114. Parkin, D.M.; Ohshima, H.; Srivatanakul, P.; Vatanasapt, V. Cholangiocarcinoma: Epidemiology, mechanisms of carcinogenesis and prevention. Cancer Epidemiol. Biomark. Prev. 1993, 2, 537-544.

115. Ames, B.N.; Gold, L.S. Chemical carcinogenesis: Too many rodent carcinogens. Proc. Natl. Acad. Sci. USA 1990, 87, 7772-7776. [CrossRef] [PubMed]

116. Cohen, S.M.; Ellwein, L.B. Cell proliferation in carcinogenesis. Science 1990, 249, 1007-1011. [CrossRef] [PubMed]

117. Weitzman, S.A.; Gordon, L.I. Inflammation and cancer: Role of phagocyte-generated oxidants in carcinogenesis. Blood 1990, 76, 655-663. [PubMed]

118. Li, X.; Wang, S.; Zhu, R.; Li, H.; Han, Q.; Zhao, R.C. Lung tumor exosomes induce a pro-inflammatory phenotype in mesenchymal stem cells via NF-kB-TLR signaling pathway. J. Hematol. Oncol. 2016, 9, 42. [CrossRef] [PubMed]

119. Chaiyadet, S.; Sotillo, J.; Smout, M.; Cantacessi, C.; Jones, M.K.; Johnson, M.S.; Turnbull, L.; Whitchurch, C.B.; Potriquet, J.; Laohaviroj, M.; et al. Carcinogenic liver fluke secretes extracellular vesicles that promote cholangiocytes to adopt a tumorigenic phenotype. J. Infect. Dis. 2015, 212, 1636-1645. [CrossRef] [PubMed]

120. Tsuchida, A.; Itoi, T. Carcinogenesis and chemoprevention of biliary tract cancer in pancreaticobiliary maljunction. World J. Gastrointest. Oncol. 2010, 2, 130-135. [CrossRef] [PubMed]

121. Tajima, Y.; Kitajima, T.; Tomioka, T.; Eto, T.; Inoue, K.; Fukahori, T.; Sasaki, M.; Tsunoda, T. Hamster Models of Biliary Carcinoma. In Hepatobiliary and Pancreatic Carcinogenesis in the Hamster; Springer: Heidelberg, Germany; Dordrecht, The Netherlands, 2009; pp. 29-68.

122. Tsuchida, A.; Itoi, T.; Kasuya, K.; Endo, M.; Katsumata, K.; Aoki, T.; Suzuki, M.; Aoki, T. Inhibitory effect of meloxicam, a cyclooxygenase-2 inhibitor, on $\mathrm{N}$-nitrosobis (2-oxopropyl) amine induced biliary carcinogenesis in Syrian hamsters. Carcinogenesis 2005, 26, 1922-1928. [CrossRef] [PubMed]

123. Bos, J.L. ras Oncogenes in human cancer: A review. Cancer Res. 1989, 49, 4682-4689. [PubMed]

124. Almoguera, C.; Shibata, D.; Forrester, K.; Martin, J.; Arnheim, N.; Perucho, M. Most human carcinomas of the exocrine pancreas contain mutant c-K-ras genes. Cell 1988, 53, 549-554. [CrossRef]

125. Boone, C.W.; Steele, V.E.; Kelloff, G.J. Screening for chemopreventive (anticarcinogenic) compounds in rodents. Mutat. Res. 1992, 267, 251-255. [CrossRef]

126. Hennings, H.; Glick, A.B.; Lowry, D.T.; Krsmanovic, L.S.; Sly, L.M.; Yuspa, S.H. FVB/N mice: An inbred strain sensitive to the chemical induction of squamous cell carcinomas in the skin. Carcinogenesis 1993, 14, 2353-2358. [CrossRef] [PubMed]

127. Nassar, D.; Latil, M.; Boeckx, B.; Lambrechts, D.; Blanpain, C. Genomic landscape of carcinogen-induced and genetically induced mouse skin squamous cell carcinoma. Nat. Med. 2015, 21, 946-954. [CrossRef] [PubMed]

128. Tazawa, H.; Tatemichi, M.; Sawa, T.; Gilibert, I.; Ma, N.; Hiraku, Y.; Donehower, L.A.; Ohgaki, H.; Kawanishi, S.; Ohshima, H. Oxidative and nitrative stress caused by subcutaneous implantation of a foreign body accelerates sarcoma development in Trp53 $3^{+/}$mice. Carcinogenesis 2007, 28, 191-198. [CrossRef] [PubMed]

129. Jennings, T.A.; Peterson, L.; Axiotis, C.A.; Friedlaender, G.E.; Cooke, R.A.; Rosai, J. Angiosarcoma associated with foreign body material. A report of three cases. Cancer 1988, 62, 2436-2444. [CrossRef]

130. Okada, F.; Kawaguchi, T.; Habelhah, H.; Kobayashi, T.; Tazawa, H.; Takeichi, N.; Kitagawa, T.; Hosokawa, M. Conversion of human colonic adenoma cells to adenocarcinoma cells through inflammation in nude mice. Lab. Investig. 2000, 80, 1617-1628. [CrossRef] [PubMed]

131. Tazawa, H.; Kawaguchi, T.; Kobayashi, T.; Kuramitsu, Y.; Wada, S.; Satomi, Y.; Nishino, H.; Kobayashi, M.; Kanda, Y.; Osaki, M.; et al. Chronic inflammation-derived nitric oxide causes conversion of human colonic adenoma cells into adenocarcinoma cells. Exp. Cell Res. 2013, 319, 2835-2844. [CrossRef] [PubMed]

132. Kanda, Y.; Kawaguchi, T.; Kuramitsu, Y.; Kitagawa, T.; Kobayashi, T.; Takahashi, N.; Tazawa, H.; Habelhah, H.; Hamada, J.; Kobayashi, M.; et al. Fascin regulates chronic inflammation-related human colon carcinogenesis by inhibiting cell anoikis. Proteomics 2014, 14, 1031-1041. [CrossRef] [PubMed]

133. Okada, F.; Hosokawa, M.; Hamada, J.I.; Hasegawa, J.; Kato, M.; Mizutani, M.; Ren, J.; Takeichi, N.; Kobayashi, H. Malignant progression of a mouse fibrosarcoma by host cells reactive to a foreign body (gelatin sponge). Br. J. Cancer 1992, 66, 635-639. [CrossRef] [PubMed] 
134. Tazawa, H.; Okada, F.; Kobayashi, T.; Tada, M.; Mori, Y.; Une, Y.; Sendo, F.; Kobayashi, M.; Hosokawa, M. Infiltration of neutrophils is required for acquisition of metastatic phenotype of benign murine fibrosarcoma cells: Implication of inflammation-associated carcinogenesis and tumor progression. Am. J. Pathol. 2003, 163, 2221-2232. [CrossRef]

135. Okada, F. Inflammation-related carcinogenesis: Current findings in epidemiological trends, causes and mechanisms. Yonago Acta Med. 2014, 57, 65-72. [PubMed]

136. Hamilton, J.A.; Achuthan, A. Colony stimulating factors and myeloid cell biology in health and disease. Trends Immunol. 2013, 34, 81-89. [CrossRef] [PubMed]

137. Yang, L.; Zhang, Y. Tumor-associated macrophages: From basic research to clinical application. J. Hematol. Oncol. 2017, 10, 58. [CrossRef] [PubMed]

138. Morales, C.; Rachidi, S.; Hong, F.; Sun, S.; Ouyang, X.; Wallace, C.; Zhang, Y.; Garret-Mayer, E.; Wu, J.; Liu, B.; et al. Immune chaperone gp96 drives the contributions of macrophages to inflammatory colon tumorigenesis. Cancer Res. 2014, 74, 446-459. [CrossRef] [PubMed]

139. Zhao, H.; Zhang, X.; Chen, X.; Li, Y.; Ke, Z.; Tang, T.; Chai, H.; Guo, A.M.; Chen, H.; Yang, J. Isoliquiritigenin, a flavonoid from licorice, blocks M2 macrophage polarization in colitis-associated tumorigenesis through downregulating $\mathrm{PGE}_{2}$ and IL-6. Toxicol. Appl. Pharmacol. 2014, 279, 311-321. [CrossRef] [PubMed]

140. Roncucci, L.; Mora, E.; Mariani, F.; Bursi, S.; Pezzi, A.; Rossi, G.; Pedroni, M.; Luppi, D.; Santoro, L.; Monni, S.; et al. Myeloperoxidase-positive cell infiltration in colorectal carcinogenesis as indicator of colorectal cancer risk. Cancer Epidemiol. Biomark. Prev. 2008, 17, 2291-2297. [CrossRef] [PubMed]

141. Coussens, L.M.; Werb, Z. Inflammation and cancer. Nature 2002, 420, 860-867. [CrossRef] [PubMed]

142. Popivanova, B.K.; Kostadinova, F.I.; Furuichi, K.; Shamekh, M.M.; Kondo, T.; Wada, T.; Egashira, K.; Mukaida, N. Blockade of a chemokine, CCL2, reduces chronic colitis-associated carcinogenesis in mice. Cancer Res. 2009, 69, 7884-7892. [CrossRef] [PubMed]

143. Horemans, T.; Boulet, G.; van Kerckhoven, M.; Bogers, J.; Thys, S.; Vervaet, C.; Vervaeck, A.; Delputte, P.; Maes, L.; Cos, P. In Vivo evaluation of apocynin for prevention of Helicobacter pylori-induced gastric carcinogenesis. Eur. J. Cancer Prev. 2017, 26, 10-16. [CrossRef] [PubMed]

144. Liu, L.; Li, Y.H.; Niu, Y.B.; Sun, Y.; Guo, Z.J.; Li, Q.; Li, C.; Feng, J.; Cao, S.S.; Mei, Q.B. An apple oligogalactan prevents against inflammation and carcinogenesis by targeting LPS/TLR4/NF- $\mathrm{B}$ pathway in a mouse model of colitis-associated colon cancer. Carcinogenesis 2010, 31, 1822-1832. [CrossRef] [PubMed]

145. Onuma, K.; Kanda, Y.; Suzuki Ikeda, S.; Sakaki, R.; Nonomura, T.; Kobayashi, M.; Osaki, M.; Shikanai, M.; Kobayashi, H.; Okada, F. Fermented brown rice and rice bran with Aspergillus oryzae (FBRA) prevents inflammation-related carcinogenesis in mice, through inhibition of inflammatory cell infiltration. Nutrients 2015, 7, 10237-10250. [CrossRef] [PubMed]

146. Sliva, D.; Loganathan, J.; Jiang, J.; Jedinak, A.; Lamb, J.G.; Terry, C.; Baldridge, L.A.; Adamec, J.; Sandusky, G.E.; Dudhgaonkar, S. Mushroom Ganoderma lucidum prevents colitis-associated carcinogenesis in mice. PLoS ONE 2012, 7, e47873. [CrossRef] [PubMed]

147. Lin, J.A.; Chen, H.C.; Yen, G.C. The preventive role of breadfruit against inflammation-associated epithelial carcinogenesis in mice. Mol. Nutr. Food Res. 2014, 58, 206-210. [CrossRef] [PubMed]

148. Im, S.A.; Kim, J.W.; Kim, H.S.; Park, C.S.; Shin, E.; Do, S.G.; Park, Y.I.; Lee, C.K. Prevention of azoxymethane/dextran sodium sulfate-induced mouse colon carcinogenesis by processed Aloe vera gel. Int. Immunopharmacol. 2016, 40, 428-435. [CrossRef] [PubMed]

149. Ju, J.; Hao, X.; Lee, M.J.; Lambert, J.D.; Lu, G.; Xiao, H.; Newmark, H.L.; Yang, C.S. A $\gamma$-tocopherol-rich mixture of tocopherols inhibits colon inflammation and carcinogenesis in azoxymethane and dextran sulfate sodium-treated mice. Cancer Prev. Res. 2009, 2, 143-152. [CrossRef] [PubMed]

150. Onuma, K.; Suenaga, Y.; Sakaki, R.; Yoshitome, S.; Sato, Y.; Ogawara, S.; Suzuki, S.; Kuramitsu, Y.; Yokoyama, H.; Murakami, A.; et al. Development of a quantitative bioassay to assess preventive compounds against inflammation-based carcinogenesis. Nitric Oxide 2011, 25, 183-194. [CrossRef] [PubMed]

151. Cao, X.; Tsukamoto, T.; Seki, T.; Tanaka, H.; Morimura, S.; Cao, L.; Mizoshita, T.; Ban, H.; Toyoda, T.; Maeda, H.; et al. 4-Vinyl-2,6-dimethoxyphenol (canolol) suppresses oxidative stress and gastric carcinogenesis in Helicobacter pylori-infected carcinogen-treated Mongolian gerbils. Int. J. Cancer 2008, 122, 1445-1454. [CrossRef] [PubMed] 
152. Du, Q.; Wang, Y.; Liu, C.; Wang, H.; Fan, H.; Li, Y.; Wang, J.; Zhang, X.; Lu, J.; Ji, H.; et al. Chemopreventive activity of GEN-27, a genistein derivative, in colitis-associated cancer is mediated by p65-CDX2- $\beta$-catenin axis. Oncotarget 2016, 7, 17870-17884. [CrossRef] [PubMed]

153. Chaudhary, S.C.; Siddiqui, M.S.; Athar, M.; Alam, M.S. Geraniol inhibits murine skin tumorigenesis by modulating COX-2 expression, Ras-ERK1/2 signaling pathway and apoptosis. J. Appl. Toxicol. 2013, 33, 828-837. [CrossRef] [PubMed]

154. Kuo, Y.C.; Lai, C.S.; Tsai, C.Y.; Nagabhushanam, K.; Ho, C.T.; Pan, M.H. Inotilone suppresses phorbol ester-induced inflammation and tumor promotion in mouse skin. Mol. Nutr. Food Res. 2012, 56, 1324-1332. [CrossRef] [PubMed]

155. Viennois, E.; Xiao, B.; Ayyadurai, S.; Wang, L.; Wang, P.G.; Zhang, Q.; Chen, Y.; Merlin, D. Micheliolide, a new sesquiterpene lactone that inhibits intestinal inflammation and colitis-associated cancer. Lab. Investig. 2014, 94, 950-965. [CrossRef] [PubMed]

156. Murakami, A.; Nakamura, Y.; Torikai, K.; Tanaka, T.; Koshiba, T.; Koshimizu, K.; Kuwahara, S.; Takahashi, Y.; Ogawa, K.; Yano, M.; et al. Inhibitory effect of citrus nobiletin on phorbol ester-induced skin inflammation, oxidative stress, and tumor promotion in mice. Cancer Res. 2000, 60, 5059-5066. [PubMed]

157. Meeker, S.; Seamons, A.; Paik, J.; Treuting, P.M.; Brabb, T.; Grady, W.M.; Maggio-Price, L. Increased dietary vitamin D suppresses MAPK signaling, colitis, and colon cancer. Cancer Res. 2014, 74, 4398-4408. [CrossRef] [PubMed]

158. Liao, J.; Seril, D.N.; Yang, A.L.; Lu, G.G.; Yang, G.Y. Inhibition of chronic ulcerative colitis associated adenocarcinoma development in mice by inositol compounds. Carcinogenesis 2007, 28, 446-454. [CrossRef] [PubMed]

159. Wei, T.T.; Lin, Y.T.; Tseng, R.Y.; Shun, C.T.; Lin, Y.C.; Wu, M.S.; Fang, J.M.; Chen, C.C. Prevention of colitis and colitis-associated colorectal cancer by a novel polypharmacological histone deacetylase inhibitor. Clin Cancer Res. 2016, 22, 4158-4169. [CrossRef] [PubMed]

160. Trivedi, P.P.; Jena, G.B.; Tikoo, K.B.; Kumar, V. Melatonin modulated autophagy and Nrf2 signaling pathways in mice with colitis-associated colon carcinogenesis. Mol. Carcinog. 2016, 55, 255-267. [CrossRef] [PubMed]

161. Chen, X.; Li, N.; Wang, S.; Hong, J.; Fang, M.; Yousselfson, J.; Yang, P.; Newman, R.A.; Lubet, R.A.; Yang, C.S. Aberrant arachidonic acid metabolism in esophageal adenocarcinogenesis, and the effects of sulindac, nordihydroguaiaretic acid, and $\alpha$-difluoromethylornithine on tumorigenesis in a rat surgical model. Carcinogenesis 2002, 23, 2095-2102. [CrossRef] [PubMed]

162. Doulberis, M.; Angelopoulou, K.; Kaldrymidou, E.; Tsingotjidou, A.; Abas, Z.; Erdman, S.E.; Poutahidis, T. Cholera-toxin suppresses carcinogenesis in a mouse model of inflammation-driven sporadic colon cancer. Carcinogenesis 2015, 36, 280-290. [CrossRef] [PubMed]

163. Ikeuchi, H.; Kinjo, T.; Klinman, D.M. Effect of suppressive oligodeoxynucleotides on the development of inflammation-induced papillomas. Cancer Prev. Res. 2011, 4, 752-757. [CrossRef] [PubMed]

164. Yasuda, M.; Nishizawa, T.; Ohigashi, H.; Tanaka, T.; Hou, D.X.; Colburn, N.H.; Murakami, A. Linoleic acid metabolite suppresses skin inflammation and tumor promotion in mice: Possible roles of programmed cell death 4 induction. Carcinogenesis 2009, 30, 1209-1216. [CrossRef] [PubMed]

165. Ohnishi, Y.; Fujii, H.; Kimura, F.; Mishima, T.; Murata, J.; Tazawa, K.; Fujimaki, M.; Okada, F.; Hosokawa, M.; Saiki, I. Inhibitory effect of a traditional Chinese medicine, Juzen-taiho-to, on progressive growth of weakly malignant clone cells derived from murine fibrosarcoma. Jpn. J. Cancer Res. 1996, 87, 1039-1044. [CrossRef] [PubMed]

166. Yum, H.W.; Zhong, X.; Park, J.; Na, H.K.; Kim, N.; Lee, H.S.; Surh, Y.J. Oligonol inhibits dextran sulfate sodium-induced colitis and colonic adenoma formation in mice. Antioxid. Redox Signal. 2013, 19, 102-114. [CrossRef] [PubMed]

167. Liu, J.; Gu, X.; Robbins, D.; Li, G.; Shi, R.; McCord, J.M.; Zhao, Y. Protandim, a fundamentally new antioxidant approach in chemoprevention using mouse two-stage skin carcinogenesis as a model. PLoS ONE 2009, 4, e5284. [CrossRef] [PubMed]

168. Miyoshi, N.; Takabayashi, S.; Osawa, T.; Nakamura, Y. Benzyl isothiocyanate inhibits excessive superoxide generation in inflammatory leukocytes: Implication for prevention against inflammation-related carcinogenesis. Carcinogenesis 2004, 25, 567-575. [CrossRef] [PubMed] 
169. Ma, J.Y.; Li, R.H.; Huang, K.; Tan, G.; Li, C.; Zhi, F.C. Increased expression and possible role of chitinase 3-like-1 in a colitis-associated carcinoma model. World J. Gastroenterol. 2014, 20, 15736-15744. [CrossRef] [PubMed]

170. Kawabata, K.; Tung, N.H.; Shoyama, Y.; Sugie, S.; Mori, T.; Tanaka, T. Dietary crocin inhibits colitis and colitis-associated colorectal carcinogenesis in male ICR mice. Evid. Based Complement. Altern. Med. eCAM 2012, 2012, 820415. [CrossRef] [PubMed]

171. Cheung, K.L.; Khor, T.O.; Huang, M.T.; Kong, A.N. Differential in vivo mechanism of chemoprevention of tumor formation in azoxymethane/dextran sodium sulfate mice by PEITC and DBM. Carcinogenesis 2010, 31, 880-885. [CrossRef] [PubMed]

172. Yang, Y.; Cai, X.; Yang, J.; Sun, X.; Hu, C.; Yan, Z.; Xu, X.; Lu, W.; Wang, X.; Cao, P. Chemoprevention of dietary digitoflavone on colitis-associated colon tumorigenesis through inducing Nrf2 signaling pathway and inhibition of inflammation. Mol. Cancer 2014, 13, 48. [CrossRef] [PubMed]

173. Tanaka, T.; de Azevedo, M.B.; Duran, N.; Alderete, J.B.; Epifano, F.; Genovese, S.; Tanaka, M.; Tanaka, T.; Curini, M. Colorectal cancer chemoprevention by $2 \beta$-cyclodextrin inclusion compounds of auraptene and 4'-geranyloxyferulic acid. Int. J. Cancer 2010, 126, 830-840. [CrossRef] [PubMed]

174. Liu, Z.; Shen, C.; Tao, Y.; Wang, S.; Wei, Z.; Cao, Y.; Wu, H.; Fan, F.; Lin, C.; Shan, Y.; et al. Chemopreventive efficacy of menthol on carcinogen-induced cutaneous carcinoma through inhibition of inflammation and oxidative stress in mice. Food Chem. Toxicol. 2015, 82, 12-18. [CrossRef] [PubMed]

175. Kuno, T.; Hatano, Y.; Tomita, H.; Hara, A.; Hirose, Y.; Hirata, A.; Mori, H.; Terasaki, M.; Masuda, S.; Tanaka, T. Organomagnesium suppresses inflammation-associated colon carcinogenesis in male Crj: CD-1 mice. Carcinogenesis 2013, 34, 361-369. [CrossRef] [PubMed]

176. Okada, F.; Shionoya, H.; Kobayashi, M.; Kobayashi, T.; Tazawa, H.; Onuma, K.; Iuchi, Y.; Matsubara, N.; Ijichi, T.; Dugas, B.; et al. Prevention of inflammation-mediated acquisition of metastatic properties of benign mouse fibrosarcoma cells by administration of an orally available superoxide dismutase. Br. J. Cancer 2006, 94, 854-862. [CrossRef] [PubMed]

177. Habelhah, H.; Okada, F.; Nakai, K.; Choi, S.K.; Hamada, J.; Kobayashi, M.; Hosokawa, M. Polysaccharide K induces Mn superoxide dismutase (Mn-SOD) in tumor tissues and inhibits malignant progression of QR-32 tumor cells: Possible roles of interferon $\alpha$, tumor necrosis factor $\alpha$ and transforming growth factor $\beta$ in Mn-SOD induction by polysaccharide K. Cancer Immunol. Immunother. 1998, 46, 338-344. [PubMed]

178. Khan, A.Q.; Khan, R.; Tahir, M.; Rehman, M.U.; Lateef, A.; Ali, F.; Hamiza, O.O.; Hasan, S.K.; Sultana, S. Silibinin inhibits tumor promotional triggers and tumorigenesis against chemically induced two-stage skin carcinogenesis in Swiss albino mice: Possible role of oxidative stress and inflammation. Nutr. Cancer 2014, 66, 249-258. [CrossRef] [PubMed]

179. Jiang, Q.; Jiang, Z.; Hall, Y.J.; Jang, Y.; Snyder, P.W.; Bain, C.; Huang, J.; Jannasch, A.; Cooper, B.; Wang, Y.; et al. $\gamma$-Tocopherol attenuates moderate but not severe colitis and suppresses moderate colitis-promoted colon tumorigenesis in mice. Free Radic. Biol. Med. 2013, 65, 1069-1077. [CrossRef] [PubMed]

180. Kim, Y.H.; Kwon, H.S.; Kim, D.H.; Shin, E.K.; Kang, Y.H.; Park, J.H.; Shin, H.K.; Kim, J.K. 3,3'-diindolylmethane attenuates colonic inflammation and tumorigenesis in mice. Inflamm. Bowel Dis. 2009, 15, 1164-1173. [CrossRef] [PubMed]

181. Xi, M.Y.; Jia, J.M.; Sun, H.P.; Sun, Z.Y.; Jiang, J.W.; Wang, Y.J.; Zhang, M.Y.; Zhu, J.F.; Xu, L.L.; Jiang, Z.Y.; et al. 3-aroylmethylene-2,3,6,7-tetrahydro-1H-pyrazino[2,1-a]isoquinolin-4(11bH)-ones as potent Nrf2/ARE inducers in human cancer cells and AOM-DSS treated mice. J. Med. Chem. 2013, 56, 7925-7938. [CrossRef] [PubMed]

182. Hamada, J.; Nakata, D.; Nakae, D.; Kobayashi, Y.; Akai, H.; Konishi, Y.; Okada, F.; Shibata, T.; Hosokawa, M.; Moriuchi, T. Increased oxidative DNA damage in mammary tumor cells by continuous epidermal growth factor stimulation. J. Natl. Cancer Inst. 2001, 93, 214-219. [CrossRef] [PubMed]

183. Sanchez-Fidalgo, S.; Villegas, I.; Cardeno, A.; Talero, E.; Sanchez-Hidalgo, M.; Motilva, V.; Alarcon de la Lastra, C. Extra-virgin olive oil-enriched diet modulates DSS-colitis-associated colon carcinogenesis in mice. Clin. Nutr. 2010, 29, 663-673. [CrossRef] [PubMed]

184. Phutthaphadoong, S.; Yamada, Y.; Hirata, A.; Tomita, H.; Hara, A.; Limtrakul, P.; Iwasaki, T.; Kobayashi, H.; Mori, H. Chemopreventive effect of fermented brown rice and rice bran (FBRA) on the inflammation-related

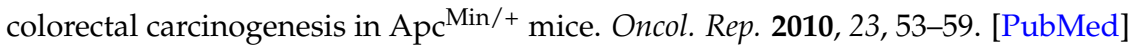


185. Yasui, Y.; Hosokawa, M.; Mikami, N.; Miyashita, K.; Tanaka, T. Dietary astaxanthin inhibits colitis and colitis-associated colon carcinogenesis in mice via modulation of the inflammatory cytokines. Chem. Biol. Interact. 2011, 193, 79-87. [CrossRef] [PubMed]

186. Ma, G.Z.; Liu, C.H.; Wei, B.; Qiao, J.; Lu, T.; Wei, H.C.; Chen, H.D.; He, C.D. Baicalein inhibits DMBA/TPA-induced skin tumorigenesis in mice by modulating proliferation, apoptosis, and inflammation. Inflammation 2013, 36, 457-467. [CrossRef] [PubMed]

187. Kim, D.H.; Sung, B.; Kang, Y.J.; Jang, J.Y.; Hwang, S.Y.; Lee, Y.; Kim, M.; Im, E.; Yoon, J.H.; Kim, C.M.; et al. Anti-inflammatory effects of betaine on AOM/DSS induced colon tumorigenesis in ICR male mice. Int. J. Oncol. 2014, 45, 1250-1256. [CrossRef] [PubMed]

188. Prakobwong, S.; Khoontawad, J.; Yongvanit, P.; Pairojkul, C.; Hiraku, Y.; Sithithaworn, P.; Pinlaor, P.; Aggarwal, B.B.; Pinlaor, S. Curcumin decreases cholangiocarcinogenesis in hamsters by suppressing inflammation-mediated molecular events related to multistep carcinogenesis. Int. J. Cancer 2011, 129, 88-100. [CrossRef] [PubMed]

189. Tsai, M.L.; Lai, C.S.; Chang, Y.H.; Chen, W.J.; Ho, C.T.; Pan, M.H. Pterostilbene, a natural analogue of resveratrol, potently inhibits 7,12-dimethylbenz[a]anthracene (DMBA)/12-O-tetradecanoylphorbol-13-acetate (TPA)-induced mouse skin carcinogenesis. Food Funct. 2012, 3, 1185-1194. [CrossRef] [PubMed]

190. Kohno, H.; Suzuki, R.; Yasui, Y.; Miyamoto, S.; Wakabayashi, K.; Tanaka, T. Ursodeoxycholic acid versus sulfasalazine in colitis-related colon carcinogenesis in mice. Clin. Cancer Res. 2007, 13, 2519-2525. [CrossRef] [PubMed]

191. Lai, C.S.; Li, S.; Chai, C.Y.; Lo, C.Y.; Ho, C.T.; Wang, Y.J.; Pan, M.H. Inhibitory effect of citrus 5-hydroxy-3,6,7,8,3', $4^{\prime}$-hexamethoxyflavone on 12-O-tetradecanoylphorbol 13-acetate-induced skin inflammation and tumor promotion in mice. Carcinogenesis 2007, 28, 2581-2588. [CrossRef] [PubMed]

192. Kohno, H.; Suzuki, R.; Sugie, S.; Tanaka, T. Suppression of colitis-related mouse colon carcinogenesis by a COX-2 inhibitor and PPAR ligands. BMC Cancer 2005, 5, 46. [CrossRef] [PubMed]

193. Shimizu, M.; Kochi, T.; Shirakami, Y.; Genovese, S.; Epifano, F.; Fiorito, S.; Mori, T.; Tanaka, T.; Moriwaki, H. A newly synthesized compound, $4^{\prime}$-geranyloxyferulic acid-N(omega)-nitro-L-arginine methyl ester suppresses inflammation-associated colorectal carcinogenesis in male mice. Int. J. Cancer 2014, 135, 774-784. [CrossRef] [PubMed]

194. Kim, Y.J.; Lee, J.S.; Hong, K.S.; Chung, J.W.; Kim, J.H.; Hahm, K.B. Novel application of proton pump inhibitor for the prevention of colitis-induced colorectal carcinogenesis beyond acid suppression. Cancer Prev. Res. 2010, 3, 963-974. [CrossRef] [PubMed]

195. Mishima, T.; Tajima, Y.; Kuroki, T.; Kosaka, T.; Adachi, T.; Kitasato, A.; Tsuneoka, N.; Kitajima, T.; Kanematsu, T. Chemopreventative effect of an inducible nitric oxide synthase inhibitor, ONO-1714, on inflammation-associated biliary carcinogenesis in hamsters. Carcinogenesis 2009, 30, 1763-1767. [CrossRef] [PubMed]

196. Guo, Y.; Liu, Y.; Zhang, C.; Su, Z.Y.; Li, W.; Huang, M.T.; Kong, A.N. The epigenetic effects of aspirin: The modification of histone $\mathrm{H} 3$ lysine 27 acetylation in the prevention of colon carcinogenesis in azoxymethaneand dextran sulfate sodium-treated CF-1 mice. Carcinogenesis 2016, 37, 616-624. [CrossRef] [PubMed]

197. Tian, Y.; Wang, K.; Wang, Z.; Li, N.; Ji, G. Chemopreventive effect of dietary glutamine on colitis-associated colon tumorigenesis in mice. Carcinogenesis 2013, 34, 1593-1600. [CrossRef] [PubMed]

198. Chung, K.S.; Choi, H.E.; Shin, J.S.; Cho, E.J.; Cho, Y.W.; Choi, J.H.; Baek, N.I.; Lee, K.T. Chemopreventive effects of standardized ethanol extract from the aerial parts of Artemisia princeps Pampanini cv. Sajabal via NF- $\mathrm{BB}$ inactivation on colitis-associated colon tumorigenesis in mice. Food Chem. Toxicol. 2015, 75, 14-23. [CrossRef] [PubMed]

199. Lavi, I.; Nimri, L.; Levinson, D.; Peri, I.; Hadar, Y.; Schwartz, B. Glucans from the edible mushroom Pleurotus pulmonarius inhibit colitis-associated colon carcinogenesis in mice. J. Gastroenterol. 2012, 47, 504-518. [CrossRef] [PubMed]

200. Oyama, T.; Yasui, Y.; Sugie, S.; Koketsu, M.; Watanabe, K.; Tanaka, T. Dietary tricin suppresses inflammation-related colon carcinogenesis in male Crj: CD-1 mice. Cancer Prev. Res. 2009, 2, 1031-1038. [CrossRef] [PubMed] 
201. Kangwan, N.; Kim, Y.J.; Han, Y.M.; Jeong, M.; Park, J.M.; Go, E.J.; Hahm, K.B. Sonic hedgehog inhibitors prevent colitis-associated cancer via orchestrated mechanisms of IL-6/gp130 inhibition, 15-PGDH induction, Bcl-2 abrogation, and tumorsphere inhibition. Oncotarget 2016, 7, 7667-7682. [PubMed]

202. Polytarchou, C.; Hommes, D.W.; Palumbo, T.; Hatziapostolou, M.; Koutsioumpa, M.; Koukos, G.; van der Meulen-de Jong, A.E.; Oikonomopoulos, A.; van Deen, W.K.; Vorvis, C.; et al. MicroRNA214 is associated with progression of ulcerative colitis, and inhibition reduces development of colitis and colitis-associated cancer in mice. Gastroenterology 2015, 149, 981-992. [CrossRef] [PubMed]

203. Yang, X.; Zhang, F.; Wang, Y.; Cai, M.; Wang, Q.; Guo, Q.; Li, Z.; Hu, R. Oroxylin A inhibits colitis-associated carcinogenesis through modulating the IL-6/STAT3 signaling pathway. Inflamm. Bowel Dis. 2013, 19, 1990-2000. [CrossRef] [PubMed]

204. Wang, Z.; Jin, H.; Xu, R.; Mei, Q.; Fan, D. Triptolide downregulates Rac1 and the JAK/STAT3 pathway and inhibits colitis-related colon cancer progression. Exp. Mol. Med. 2009, 41, 717-727. [CrossRef] [PubMed]

205. Altamemi, I.; Murphy, E.A.; Catroppo, J.F.; Zumbrun, E.E.; Zhang, J.; McClellan, J.L.; Singh, U.P.; Nagarkatti, P.S.; Nagarkatti, M. Role of microRNAs in resveratrol-mediated mitigation of colitis-associated tumorigenesis in Apc ${ }^{\mathrm{Min} /+}$ mice. J. Pharmacol. Exp. Ther. 2014, 350, 99-109. [CrossRef] [PubMed]

206. Zhang, L.; Han, J.; Jackson, A.L.; Clark, L.N.; Kilgore, J.; Guo, H.; Livingston, N.; Batchelor, K.; Yin, Y.; Gilliam, T.P.; et al. NT1014, a novel biguanide, inhibits ovarian cancer growth in vitro and in vivo. J. Hematol. Oncol. 2016, 9, 91. [CrossRef] [PubMed]

207. Niwa, T.; Toyoda, T.; Tsukamoto, T.; Mori, A.; Tatematsu, M.; Ushijima, T. Prevention of Helicobacter pylori-induced gastric cancers in gerbils by a DNA demethylating agent. Cancer Prev. Res. 2013, 6, 263-270. [CrossRef] [PubMed]

208. Yamaguchi, M.; Takai, S.; Hosono, A.; Seki, T. Bovine milk-derived $\alpha$-lactalbumin inhibits colon inflammation and carcinogenesis in azoxymethane and dextran sodium sulfate-treated mice. Biosci. Biotechnol. Biochem. 2014, 78, 672-679. [CrossRef] [PubMed]

209. Piazzi, G.; D’Argenio, G.; Prossomariti, A.; Lembo, V.; Mazzone, G.; Candela, M.; Biagi, E.; Brigidi, P.; Vitaglione, P.; Fogliano, V.; et al. Eicosapentaenoic acid free fatty acid prevents and suppresses colonic neoplasia in colitis-associated colorectal cancer acting on Notch signaling and gut microbiota. Int. J. Cancer 2014, 135, 2004-2013. [CrossRef] [PubMed]

210. Kuo, C.H.; Hu, H.M.; Tsai, P.Y.; Wu, I.C.; Yang, S.F.; Chang, L.L.; Wang, J.Y.; Jan, C.M.; Wang, W.M.; Wu, D.C. Short-term celecoxib intervention is a safe and effective chemopreventive for gastric carcinogenesis based on a Mongolian gerbil model. World J. Gastroenterol. 2009, 15, 4907-4914. [CrossRef] [PubMed]

211. Buttar, N.S.; Wang, K.K.; Leontovich, O.; Westcott, J.Y.; Pacifico, R.J.; Anderson, M.A.; Krishnadath, K.K.; Lutzke, L.S.; Burgart, L.J. Chemoprevention of esophageal adenocarcinoma by COX-2 inhibitors in an animal model of Barrett's esophagus. Gastroenterology 2002, 122, 1101-1112. [CrossRef] [PubMed]

212. Schieber, M.; Chandel, N.S. ROS function in redox signaling and oxidative stress. Curr. Biol. 2014, 24, R453-R462. [CrossRef] [PubMed]

213. Barja, G. Rate of generation of oxidative stress-related damage and animal longevity. Free Radic. Biol. Med. 2002, 33, 1167-1172. [CrossRef]

214. Kundu, J.K.; Surh, Y.J. Emerging avenues linking inflammation and cancer. Free Radic. Biol. Med. 2012, 52, 2013-2037. [CrossRef] [PubMed]

215. Medzhitov, R. Origin and physiological roles of inflammation. Nature 2008, 454, 428-435. [CrossRef] [PubMed]

216. Sumimoto, H. Structure, regulation and evolution of Nox-family NADPH oxidases that produce reactive oxygen species. FEBS J. 2008, 275, 3249-3277. [CrossRef] [PubMed]

217. Davtyan, T.K.; Manukyan, H.M.; Hakopyan, G.S.; Mkrtchyan, N.R.; Avetisyan, S.A.; Galoyan, A.A. Hypothalamic proline-rich polypeptide is an oxidative burst regulator. Neurochem. Res. 2005, 30, 297-309. [CrossRef] [PubMed]

218. Okada, F.; Kobayashi, M.; Tanaka, H.; Kobayashi, T.; Tazawa, H.; Iuchi, Y.; Onuma, K.; Hosokawa, M.; Dinauer, M.C.; Hunt, N.H. The role of nicotinamide adenine dinucleotide phosphate oxidase-derived reactive oxygen species in the acquisition of metastatic ability of tumor cells. Am. J. Pathol. 2006, 169, $294-302$. [CrossRef] [PubMed] 
219. Nair, J.; Gansauge, F.; Beger, H.; Dolara, P.; Winde, G.; Bartsch, H. Increased etheno-DNA adducts in affected tissues of patients suffering from Crohn's disease, ulcerative colitis, and chronic pancreatitis. Antioxid. Redox Signal. 2006, 8, 1003-1010. [CrossRef] [PubMed]

220. Ambs, S.; Merriam, W.G.; Bennett, W.P.; Felley-Bosco, E.; Ogunfusika, M.O.; Oser, S.M.; Klein, S.; Shields, P.G.; Billiar, T.R.; Harris, C.C. Frequent nitric oxide synthase-2 expression in human colon adenomas: Implication for tumor angiogenesis and colon cancer progression. Cancer Res. 1998, 58, 334-341. [PubMed]

221. Wilson, K.T.; Fu, S.; Ramanujam, K.S.; Meltzer, S.J. Increased expression of inducible nitric oxide synthase and cyclooxygenase-2 in Barrett's esophagus and associated adenocarcinomas. Cancer Res. 1998, 58, 2929-2934. [PubMed]

222. Sawa, T.; Ohshima, H. Nitrative DNA damage in inflammation and its possible role in carcinogenesis. Nitric Oxide 2006, 14, 91-100. [CrossRef] [PubMed]

223. Okada, F.; Nakai, K.; Kobayashi, T.; Shibata, T.; Tagami, S.; Kawakami, Y.; Kitazawa, T.; Kominami, R.; Yoshimura, S.; Suzuki, K.; et al. Inflammatory cell-mediated tumour progression and minisatellite mutation correlate with the decrease of antioxidative enzymes in murine fibrosarcoma cells. Br. J. Cancer 1999, 79, 377-385. [CrossRef] [PubMed]

224. Korantzopoulos, P.; Kolettis, T.M.; Kountouris, E.; Dimitroula, V.; Karanikis, P.; Pappa, E.; Siogas, K.; Goudevenos, J.A. Oral vitamin C administration reduces early recurrence rates after electrical cardioversion of persistent atrial fibrillation and attenuates associated inflammation. Int. J. Cardiol. 2005, 102, 321-326. [CrossRef] [PubMed]

225. Jiang, Q.; Lykkesfeldt, J.; Shigenaga, M.K.; Shigeno, E.T.; Christen, S.; Ames, B.N. $\gamma$-tocopherol supplementation inhibits protein nitration and ascorbate oxidation in rats with inflammation. Free Radic. Biol. Med. 2002, 33, 1534-1542. [CrossRef]

226. Christen, S.; Woodall, A.A.; Shigenaga, M.K.; Southwell-Keely, P.T.; Duncan, M.W.; Ames, B.N. $\gamma$-Tocopherol traps mutagenic electrophiles such as $\mathrm{NO}_{\mathrm{X}}$ and complements $\alpha$-tocopherol: Physiological implications. Proc. Natl. Acad. Sci. USA 1997, 94, 3217-3222. [CrossRef] [PubMed]

227. Decker, E.A.; Xu, Z.M. Minimizing rancidity in muscle foods. Food Technol. 1998, 52, 54-59.

228. Kim, H.J.; Kim, M.K.; Chang, W.K.; Choi, H.S.; Choi, B.Y.; Lee, S.S. Effect of nutrient intake and Helicobacter pylori infection on gastric cancer in Korea: A case-control study. Nutr. Cancer 2005, 52, 138-146. [CrossRef] [PubMed]

229. Ohshima, H.; Tazawa, H.; Sylla, B.S.; Sawa, T. Prevention of human cancer by modulation of chronic inflammatory processes. Mutat. Res. 2005, 591, 110-122. [CrossRef] [PubMed]

230. Lu, H.; Ouyang, W.; Huang, C. Inflammation, a key event in cancer development. Mol. Cancer Res. 2006, 4, 221-233. [CrossRef] [PubMed]

231. Schuliga, M. NF-кB signaling in chronic inflammatory airway disease. Biomolecules 2015, 5, 1266-1283. [CrossRef] [PubMed]

232. Tak, P.P.; Firestein, G.S. NF-кB: A key role in inflammatory diseases. J. Clin. Investig. 2001, 107, 7-11. [CrossRef] [PubMed]

233. Solt, L.A.; May, M.J. The IкB kinase complex: Master regulator of NF-кB signaling. Immunol. Res. 2008, 42, 3-18. [CrossRef] [PubMed]

234. Morgan, M.J.; Liu, Z.G. Crosstalk of reactive oxygen species and NF-kB signaling. Cell Res. 2011, 21, $103-115$. [CrossRef] [PubMed]

235. Blaser, H.; Dostert, C.; Mak, T.W.; Brenner, D. TNF and ROS crosstalk in inflammation. Trends Cell Biol. 2016, 26, 249-261. [CrossRef] [PubMed]

236. Kagoya, Y.; Yoshimi, A.; Kataoka, K.; Nakagawa, M.; Kumano, K.; Arai, S.; Kobayashi, H.; Saito, T.; Iwakura, Y.; Kurokawa, M. Positive feedback between NF-kB and TNF- $\alpha$ promotes leukemia-initiating cell capacity. J. Clin. Investig. 2014, 124, 528-542. [CrossRef] [PubMed]

237. Peng, D.F.; Hu, T.L.; Soutto, M.; Belkhiri, A.; El-Rifai, W. Loss of glutathione peroxidase 7 promotes TNF- $\alpha$-induced NF- $\kappa$ B activation in Barrett's carcinogenesis. Carcinogenesis 2014, 35, 1620-1628. [CrossRef] [PubMed]

238. Thompson, P.A.; Khatami, M.; Baglole, C.J.; Sun, J.; Harris, S.A.; Moon, E.Y.; Al-Mulla, F.; Al-Temaimi, R.; Brown, D.G.; Colacci, A.; et al. Environmental immune disruptors, inflammation and cancer risk. Carcinogenesis 2015, 36 (Suppl. S1), S232-S253. [CrossRef] [PubMed] 
239. Schetter, A.J.; Heegaard, N.H.; Harris, C.C. Inflammation and cancer: Interweaving microRNA, free radical, cytokine and p53 pathways. Carcinogenesis 2010, 31, 37-49. [CrossRef] [PubMed]

240. Riva, F.; Bonavita, E.; Barbati, E.; Muzio, M.; Mantovani, A.; Garlanda, C. TIR8/SIGIRR is an interleukin-1 receptor/toll like receptor family member with regulatory functions in inflammation and immunity. Front. Immunol. 2012, 3, 322. [CrossRef] [PubMed]

241. Moore, R.J.; Owens, D.M.; Stamp, G.; Arnott, C.; Burke, F.; East, N.; Holdsworth, H.; Turner, L.; Rollins, B.; Pasparakis, M.; et al. Mice deficient in tumor necrosis factor- $\alpha$ are resistant to skin carcinogenesis. Nat. Med. 1999, 5, 828-831. [PubMed]

242. Yoshida, G.J. Therapeutic strategies of drug repositioning targeting autophagy to induce cancer cell death: From pathophysiology to treatment. J. Hematol. Oncol. 2017, 10, 67. [CrossRef] [PubMed]

243. Wang, L.; Fu, H.; Nanayakkara, G.; Li, Y.; Shao, Y.; Johnson, C.; Cheng, J.; Yang, W.Y.; Yang, F.; Lavallee, M.; et al. Novel extracellular and nuclear caspase-1 and inflammasomes propagate inflammation and regulate gene expression: A comprehensive database mining study. J. Hematol. Oncol. 2016, 9, 122. [CrossRef] [PubMed]

244. Lin, C.; Zhang, J. Inflammasomes in inflammation-induced cancer. Front. Immunol. 2017, 8, 271. [CrossRef] [PubMed]

245. Terlizzi, M.; Casolaro, V.; Pinto, A.; Sorrentino, R. Inflammasome: Cancer's friend or foe? Pharmacol. Ther. 2014, 143, 24-33. [CrossRef] [PubMed]

246. Michopoulou, A.; Rousselle, P. How do epidermal matrix metalloproteinases support re-epithelialization during skin healing? Eur. J. Dermatol. 2015, 25, 33-42. [PubMed]

247. Knight, D. Epithelium-fibroblast interactions in response to airway inflammation. Immunol. Cell Biol. 2001, 79, 160-164. [CrossRef] [PubMed]

248. Martin, P.; Hopkinson-Woolley, J.; McCluskey, J. Growth factors and cutaneous wound repair. Prog. Growth Factor Res. 1992, 4, 25-44. [CrossRef]

249. Nagayasu, H.; Hamada, J.; Nakata, D.; Shibata, T.; Kobayashi, M.; Hosokawa, M.; Takeichi, N. Reversible and irreversible tumor progression of a weakly malignant rat mammary carcinoma cell line by in vitro exposure to epidermal growth factor. Int. J. Oncol. 1998, 12, 197-202. [CrossRef] [PubMed]

250. Sun, J.; Madan, R.; Karp, C.L.; Braciale, T.J. Effector T cells control lung inflammation during acute influenza virus infection by producing IL-10. Nat. Med. 2009, 15, 277-284. [CrossRef] [PubMed]

251. Schottelius, A.J.; Mayo, M.W.; Sartor, R.B.; Baldwin, A.S., Jr. Interleukin-10 signaling blocks inhibitor of КB kinase activity and nuclear factor КB DNA binding. J. Biol. Chem. 1999, 274, 31868-31874. [CrossRef] [PubMed]

252. Sturlan, S.; Oberhuber, G.; Beinhauer, B.G.; Tichy, B.; Kappel, S.; Wang, J.; Rogy, M.A. Interleukin-10-deficient mice and inflammatory bowel disease associated cancer development. Carcinogenesis 2001, 22, 665-671. [CrossRef] [PubMed]

253. Kim, S.J.; Ryu, K.J.; Hong, M.; Ko, Y.H.; Kim, W.S. The serum CXCL13 level is associated with the Glasgow Prognostic Score in extranodal NK/T-cell lymphoma patients. J. Hematol. Oncol. 2015, 8, 49. [CrossRef] [PubMed]

254. Reinecker, H.C.; Loh, E.Y.; Ringler, D.J.; Mehta, A.; Rombeau, J.L.; MacDermott, R.P. Monocyte-chemoattractant protein 1 gene expression in intestinal epithelial cells and inflammatory bowel disease mucosa. Gastroenterology 1995, 108, 40-50. [CrossRef]

255. Nasrallah, R.; Hassouneh, R.; Hebert, R.L. PGE2, kidney disease, and cardiovascular risk: Beyond hypertension and diabetes. J. Am. Soc. Nephrol. 2016, 27, 666-676. [CrossRef] [PubMed]

256. Miyaura, C.; Inada, M.; Matsumoto, C.; Ohshiba, T.; Uozumi, N.; Shimizu, T.; Ito, A. An essential role of cytosolic phospholipase A2 $\alpha$ in prostaglandin E2-mediated bone resorption associated with inflammation. J. Exp. Med. 2003, 197, 1303-1310. [CrossRef] [PubMed]

257. Sahin, M.; Sahin, E.; Gumuslu, S. Cyclooxygenase-2 in cancer and angiogenesis. Angiology 2009, 60, $242-253$. [CrossRef] [PubMed]

258. Usman, M.W.; Luo, F.; Cheng, H.; Zhao, J.J.; Liu, P. Chemopreventive effects of aspirin at a glance. Biochim. Biophys. Acta 2015, 1855, 254-263. [CrossRef] [PubMed]

259. IARC Working Group on the Evaluation of Cancer-Preventive Agents; International Agency for Research on Cancer. Non-Steroidal Anti-Inflammatory Drugs; International Agency for Research on Cancer: Lyon, France, 1997. 
260. Flossmann, E.; Rothwell, P.M. British Doctors Aspirin Trial and the UK-TIA Aspirin Trial. Effect of aspirin on long-term risk of colorectal cancer: Consistent evidence from randomised and observational studies. Lancet 2007, 369, 1603-1613. [CrossRef]

261. Cuzick, J.; Otto, F.; Baron, J.A.; Brown, P.H.; Burn, J.; Greenwald, P.; Jankowski, J.; La Vecchia, C.; Meyskens, F.; Senn, H.J.; et al. Aspirin and non-steroidal anti-inflammatory drugs for cancer prevention: An international consensus statement. Lancet Oncol. 2009, 10, 501-507. [CrossRef]

262. Harris, R.E.; Casto, B.C.; Harris, Z.M. Cyclooxygenase-2 and the inflammogenesis of breast cancer. World J. Clin. Oncol. 2014, 5, 677-692. [CrossRef] [PubMed]

263. Rao, P.; Knaus, E.E. Evolution of nonsteroidal anti-inflammatory drugs (NSAIDs): Cyclooxygenase (COX) inhibition and beyond. J. Pharm. Pharm. Sci. 2008, 11, 81s-110s. [CrossRef] [PubMed]

264. Fowler, T.O.; Durham, C.O.; Planton, J.; Edlund, B.J. Use of nonsteroidal anti-inflammatory drugs in the older adult. J. Am. Assoc. Nurse Pract. 2014, 26, 414-423. [CrossRef] [PubMed]

265. Nguyen, D.M.; Richardson, P.; El-Serag, H.B. Medications (NSAIDs, statins, proton pump inhibitors) and the risk of esophageal adenocarcinoma in patients with Barrett's esophagus. Gastroenterology 2010, 138, 2260-2266. [CrossRef] [PubMed]

266. Guerra, C.; Collado, M.; Navas, C.; Schuhmacher, A.J.; Hernandez-Porras, I.; Canamero, M.; Rodriguez-Justo, M.; Serrano, M.; Barbacid, M. Pancreatitis-induced inflammation contributes to pancreatic cancer by inhibiting oncogene-induced senescence. Cancer Cell 2011, 19, 728-739. [CrossRef] [PubMed]

267. Henderson, A.J.; Ollila, C.A.; Kumar, A.; Borresen, E.C.; Raina, K.; Agarwal, R.; Ryan, E.P. Chemopreventive properties of dietary rice bran: Current status and future prospects. Adv. Nutr. 2012, 3, 643-653. [CrossRef] [PubMed]

268. Kelloff, G.J.; Crowell, J.A.; Steele, V.E.; Lubet, R.A.; Malone, W.A.; Boone, C.W.; Kopelovich, L.; Hawk, E.T.; Lieberman, R.; Lawrence, J.A.; et al. Progress in cancer chemoprevention: Development of diet-derived chemopreventive agents. J. Nutr. 2000, 130 (Suppl. S2), S467-S471. [CrossRef]

269. Thun, M.J.; DeLancey, J.O.; Center, M.M.; Jemal, A.; Ward, E.M. The global burden of cancer: Priorities for prevention. Carcinogenesis 2010, 31, 100-110. [CrossRef] [PubMed]

270. Li, Z.; Zheng, Z.; Ruan, J.; Li, Z.; Tzeng, C.M. Chronic inflammation links cancer and Parkinson's disease. Front. Aging Neurosci. 2016, 8, 126. [CrossRef] [PubMed]

271. Levy Nogueira, M.; da Veiga Moreira, J.; Baronzio, G.F.; Dubois, B.; Steyaert, J.M.; Schwartz, L. Mechanical stress as the common denominator between chronic inflammation, cancer, and Alzheimer's disease. Front. Oncol. 2015, 5, 197. [CrossRef] [PubMed]

272. Pawelec, G.; Goldeck, D.; Derhovanessian, E. Inflammation, ageing and chronic disease. Curr. Opin. Immunol. 2014, 29, 23-28. [CrossRef] [PubMed]

273. Leonard, B.E. Inflammation, depression and dementia: Are they connected? Neurochem. Res. 2007, 32, 1749-1756. [CrossRef] [PubMed]

274. Stange, E.F.; Wehkamp, J. Recent advances in understanding and managing Crohn's disease. F1000Res. 2016, 5, 2896. [CrossRef] [PubMed]

275. Hajebrahimi, B.; Kiamanesh, A.; Asgharnejad Farid, A.A.; Asadikaram, G. Type 2 diabetes and mental disorders; a plausible link with inflammation. Cell. Mol. Biol. 2016, 62, 71-77. [CrossRef] [PubMed]

276. Fougere, B.; Boulanger, E.; Nourhashemi, F.; Guyonnet, S.; Cesari, M. Chronic inflammation: Accelerator of biological aging. J. Gerontol. A Biol. Sci. Med. Sci. 2016. [CrossRef] [PubMed]

277. Viola, J.; Soehnlein, O. Atherosclerosis-A matter of unresolved inflammation. Semin. Immunol. 2015, 27, 184-193. [CrossRef] [PubMed]

278. Van den Hoogen, P.; van den Akker, F.; Deddens, J.C.; Sluijter, J.P. Heart failure in chronic myocarditis: A role for microRNAs? Curr. Genom. 2015, 16, 88-94. [CrossRef] [PubMed]

279. Podolska, M.J.; Biermann, M.H.; Maueroder, C.; Hahn, J.; Herrmann, M. Inflammatory etiopathogenesis of systemic lupus erythematosus: An update. J. Inflamm. Res. 2015, 8, 161-171. [PubMed]

280. De Souza, A.W.; de Carvalho, J.F. Diagnostic and classification criteria of Takayasu arteritis. J. Autoimmun. 2014, 48-49, 79-83. [CrossRef] [PubMed]

281. Zhernakova, A.; Withoff, S.; Wijmenga, C. Clinical implications of shared genetics and pathogenesis in autoimmune diseases. Nat. Rev. Endocrinol. 2013, 9, 646-659. [CrossRef] [PubMed]

282. Monteiro, R.; Azevedo, I. Chronic inflammation in obesity and the metabolic syndrome. Mediat. Inflamm. 2010, 2010, 289645. [CrossRef] [PubMed] 
283. David, J.; Ansell, B.M.; Woo, P. Polyarteritis nodosa associated with streptococcus. Arch. Dis. Child. 1993, 69, 685-688. [CrossRef] [PubMed]

284. Hirose, N.; Arai, Y.; Gondoh, Y.; Nakazawa, S.; Takayama, M.; Ebihara, Y.; Shimizu, K.; Inagaki, H.; Masui, Y.; Kitagawa, K.; et al. Tokyo centenarian study: Aging inflammation hypothesis. Geriatr. Gerontol. Int. 2004, 4, S182-S185. [CrossRef]

285. Kamp, D.W.; Shacter, E.; Weitzman, S.A. Chronic inflammation and cancer: The role of the mitochondria. Oncology 2011, 25, 400-413. [PubMed]

(c)

(C) 2017 by the authors. Licensee MDPI, Basel, Switzerland. This article is an open access article distributed under the terms and conditions of the Creative Commons Attribution (CC BY) license (http:/ / creativecommons.org/licenses/by/4.0/). 